\title{
Interfacial mechanisms of heterogeneous Fenton reactions catalyzed by iron-based materials: A review
}

\author{
Jie $\mathrm{He}^{* *, 1,2}$, Xiaofang Yang,**,1, Bin Men ${ }^{1}$, Dongsheng Wang,1
}

1. State Key Laboratory of Environmental Aquatic Chemistry, Research Center for Eco-Environmental Sciences, Chinese Academy of Sciences, Beijing 100085, China. E-mail: hejie10@mails.ucas.ac.cn

2. University of Chinese Academy of Sciences, Beijing 100049, China

\section{A R T I C L E I N F O}

Article history:

Received 31 July 2015

Revised 28 November 2015

Accepted 1 December 2015

Available online 28 December 2015

Keywords:

Heterogeneous Fenton reactions ROS

interfacial mechanisms

iron-based materials

\begin{abstract}
A B S T R A C T
The heterogeneous Fenton reaction can generate highly reactive hydroxyl radicals $(. \mathrm{OH})$ from reactions between recyclable solid catalysts and $\mathrm{H}_{2} \mathrm{O}_{2}$ at acidic or even circumneutral $\mathrm{pH}$. Hence, it can effectively oxidize refractory organics in water or soils and has become a promising environmentally friendly treatment technology. Due to the complex reaction system, the mechanism behind heterogeneous Fenton reactions remains unresolved but fascinating, and is crucial for understanding Fenton chemistry and the development and application of efficient heterogeneous Fenton technologies. Iron-based materials usually possess high catalytic activity, low cost, negligible toxicity and easy recovery, and are a superior type of heterogeneous Fenton catalysts. Therefore, this article reviews the fundamental but important interfacial mechanisms of heterogeneous Fenton reactions catalyzed by iron-based materials. .OH, hydroperoxyl radicals/superoxide anions $\left(\mathrm{HO}_{2} / \mathrm{O}_{2}^{-}\right.$.) and high-valent iron are the three main types of reactive oxygen species (ROS), with different oxidation reactivity and selectivity. Based on the mechanisms of ROS generation, the interfacial mechanisms of heterogeneous Fenton systems can be classified as the homogeneous Fenton mechanism induced by surface-leached iron, the heterogeneous catalysis mechanism, and the heterogeneous reaction-induced homogeneous mechanism. Different heterogeneous Fenton systems catalyzed by characteristic iron-based materials are comprehensively reviewed. Finally, related future research directions are also suggested.
\end{abstract}

(c) 2015 The Research Center for Eco-Environmental Sciences, Chinese Academy of Sciences. Published by Elsevier B.V.

\section{Introduction}

As one of the advanced oxidation processes (AOPs), heterogeneous Fenton reactions can effectively degrade refractory organics in water or soils (Andreozzi et al., 2002a; Kitis and Kaplan, 2007; Lücking et al., 1998; Melero et al., 2009; Mesquita et al., 2012; Pignatello et al., 2006; Zhang et al., 2011). Highly reactive hydroxyl radicals $(. \mathrm{OH})$ are generated from reactions between recyclable solid catalysts and $\mathrm{H}_{2} \mathrm{O}_{2}$ at acidic or even circumneutral pH ranges (Pignatello et al., 2006; Seyed Dorraji et al., 2015; Xu and Wang, 2012b; Xue et al., 2009a). Hence, heterogeneous Fenton reactions have attracted wide attention.

The heterogeneous Fenton reaction was discovered about 100 years after the discovery of the classic homogeneous Fenton reaction (i.e., the reaction between $\mathrm{Fe}^{2+}$ and $\mathrm{H}_{2} \mathrm{O}_{2}$ ) in 1894 (Pignatello et al., 2006; Tyre et al., 1991). It can overcome the disadvantages of the homogeneous Fenton reaction, such

\footnotetext{
* Corresponding author. E-mail: xfyang@rcees.ac.cn (Xiaofang Yang), wgds@rcees.ac.cn (Dongsheng Wang).

** The authors contributed equally to this article.
} 
as decreasing reactivity due to catalyst consumption and the need for sludge treatment due to $\mathrm{pH}$ adjustments. However, unlike the well-known homogeneous Fenton mechanism, the mechanism behind heterogeneous Fenton reactions remains unresolved but fascinating, due to the complex interactions among solid catalysts, $\mathrm{H}_{2} \mathrm{O}_{2}$, parent organic compounds, generated reactive oxygen species (ROS), degradation byproducts and other co-existing substrates. To understand the reaction mechanisms is crucial for understanding Fenton chemistry and the development and application of efficient heterogeneous Fenton technologies.

Interface reactions include the generation and utilization of ROS, and are vital parts of heterogeneous Fenton mechanism. Different from other published reviews, which have focused on the preparation and performance of the catalysts (Dhakshinamoorthy et al., 2012; Garrido-Ramirez et al., 2010; Navalon et al., 2010a; Nidheesh, 2015; Perathoner and Centi, 2005), this article reviews the fundamental interfacial mechanisms of the heterogeneous Fenton reactions catalyzed by iron-based materials, which may also provide insights for the enhancement of heterogeneous Fenton reactions with additional energy, such as ultraviolet and visible light (UV-Vis), electricity, and ultrasound.

\section{ROS in heterogeneous Fenton systems}

In the heterogeneous Fenton systems catalyzed by iron-based materials, ROS are responsible for the degradation of organic contaminants, due to the limited adsorption capacity of catalysts and the weak oxidation potential of $\mathrm{H}_{2} \mathrm{O}_{2}$. Though the ROS generated remain controversial (Pham et al., 2009), . $\mathrm{OH}, \mathrm{HO}_{2} / \mathrm{O}_{2}^{-}$. and high-valent iron species are the three main types of ROS.

\section{1. $\cdot \mathrm{OH}$}

Hydroxyl radical (.OH) is the most commonly detected oxidant in heterogeneous Fenton systems. It can be generated from heterogeneous reactions between surface $\mathrm{Fe}^{\mathrm{II}}\left(\equiv \mathrm{Fe}^{\mathrm{II}}\right)$ and $\mathrm{H}_{2} \mathrm{O}_{2}$ (Eq. (1) (Lin and Gurol, 1998)) (detailed in Section 2.2), and might also be generated from the outer-sphere reaction between $\mathrm{Fe}^{2+}$ and $\mathrm{H}_{2} \mathrm{O}_{2}$ at acidic $\mathrm{pH}$, which leads to homolytic O-O bond cleavage (Remucal and Sedlak, 2011), i.e., a homogeneous Fenton reaction induced by the leached iron (detailed in Section 2.1).

$\equiv \mathrm{Fe}^{\mathrm{II}}+\mathrm{H}_{2} \mathrm{O}_{2} \rightarrow \equiv \mathrm{Fe}^{\mathrm{III}}-\mathrm{OH}+\cdot \mathrm{OH}$

With a high reduction potential (Table 1$), \cdot \mathrm{OH}$ is a strong and nonselective oxidant, and is able to react with various organic compounds at near-diffusion controlled rates (Keenan and Sedlak, 2008) (Table 2). Reactions between .OH and organic compounds include abstraction of $\mathrm{H}$ atoms from $\mathrm{C}-\mathrm{H}, \mathrm{N}-\mathrm{H}$, or $\mathrm{O}-\mathrm{H}$ bonds, and $\mathrm{OH}$ addition to unsaturated bonds like $\mathrm{C}=\mathrm{C}$ bonds or aromatic rings (Pignatello et al., 2006; Xu and Wang, 2012a).

Since the half-life of. $\mathrm{OH}$ radical is on the order of a few nanoseconds (BaČIĆ and MojoviĆ, 2005), and the .OH migration distance is only micro-meters,. $\mathrm{OH}$ radical can only be
Table 1-Physicochemical properties of three main reactive oxygen species (ROS).

\begin{tabular}{|c|c|c|}
\hline ROS & Standard reduction potential & Half-life (sec) \\
\hline. $\mathrm{OH}$ & $E_{\mathrm{H}}^{\mathrm{o}}\left(. \mathrm{OH} / \mathrm{H}_{2} \mathrm{O}\right)=2.59 \mathrm{~V}^{\mathrm{a}}$ & $10^{-9 d}$ \\
\hline $\mathrm{HO}_{2} / \mathrm{O}_{2}^{-}$ & $E_{\mathrm{H}}^{0}\left(\mathrm{HO}_{2} / \mathrm{H}_{2} \mathrm{O}_{2}\right)=1.50 \mathrm{~V}^{\mathrm{b}}$ & $10^{-5 d}$ \\
\hline $\mathrm{Fe}(\mathrm{IV})$ & $E_{\mathrm{H}}^{0}\left(\mathrm{Fe}^{4+} / \mathrm{Fe}^{3+}\right) \approx 1.80 \mathrm{~V}^{\mathrm{c}}$ & $\sim 0.35^{\mathrm{c}}$ \\
\hline \multicolumn{3}{|c|}{ a Remucal and Sedlak, 2011.} \\
\hline \multicolumn{3}{|c|}{ b Vanýsek, 2011.} \\
\hline \multirow{2}{*}{\multicolumn{3}{|c|}{ c Bossmann et al., 1998.}} \\
\hline & Mojović, 2005 & \\
\hline
\end{tabular}

detected indirectly at present. (1) The reaction between .OH and spin trap agents can form more stable adducts, which can be easily detected by electron spin resonance (ESR) spectroscopy. For example, .OH reacts with 5,5-dimethyl-1-pyrroline-N-oxide (DMPO) to form DMPO-OH adduct, which has a half-life of 12-156 min in neutral solutions (Faure et al., 2012) and exhibits a characteristic ESR spectrum for detection. (2) Inorganic ions like $\mathrm{HCO}_{3}^{-}$and $\mathrm{PO}_{4}^{3-} / \mathrm{HPO}_{4}^{2-} / \mathrm{H}_{2} \mathrm{PO}_{4}^{-}$, and alcohols like n-butanol, t-butanol, methanol and ethanol consume .OH quickly (Table 2). Hence, they are used as .OH scavengers to inhibit.OH-dominated degradation, and serve as important indicators of. $\mathrm{OH}$ (Gonzalez-Olmos et al., 2011; Xu and Wang, 2012a; Zelmanov and Semiat, 2008). $\mathrm{I}^{-}$acts as efficient scavenger of surface-bound . $\mathrm{OH}$ (Xu and Wang, 2011). The scavenging of .OH by $\mathrm{Cl}^{-}$is significant only at low pH (Grebel et al., 2010) (e.g., $\mathrm{pH}<2$ (Machulek et al., 2006)), while carbonate scavenging of .OH increases with pH (Grebel et al., 2010). (3) The respective stoichiometric reaction between $\mathrm{OH}$ and coumarin, terephthalic acid or DMSO can produce fluorescent or colored products, and can be used for .OH quantification (Huang et al., 2013; Luo et al., 2010; Steiner and Babbs, 1990; Yan et al., 2012). (4) A series of hydroxylated products detected during contaminant degradation can also indicate $\cdot \mathrm{OH}$ existence (Costa et al., 2006, 2008).

\section{2. $\mathrm{HO}_{2} / \mathrm{O}_{2}$}

Hydroperoxyl radical $\left(\mathrm{HO}_{2}\right.$.) and its conjugated base, superoxide anion $\left(\mathrm{O}_{2}^{-}\right.$.) (Eq. (2) (Pignatello et al., 2006)), are usually detected and accompanied by .OH. They are generated from the reaction between surface-complexed $\mathrm{Fe}^{\mathrm{III}}\left(\equiv \mathrm{Fe}^{\mathrm{III}} \mathrm{OH}\right)$ and $\mathrm{H}_{2} \mathrm{O}_{2}$ (detailed in Section 2.2), the reaction between .OH and $\mathrm{H}_{2} \mathrm{O}_{2}$, and reactions between carbon-centered free radicals and $\mathrm{O}_{2}$ (Eqs. (3)-(5) (Lin and Gurol, 1998; Pignatello et al., 2006)).

$\mathrm{O}_{2} \cdot{ }^{-}+\mathrm{H}^{+} \leftrightarrow \mathrm{HO}_{2} . \quad p K_{\mathrm{a}}=4.85 \pm 0.1$

$\equiv \mathrm{Fe}^{\mathrm{III}}-\mathrm{OH}+\mathrm{H}_{2} \mathrm{O}_{2} \rightarrow \equiv \mathrm{Fe}^{\mathrm{II}}+\mathrm{H}_{2} \mathrm{O}+\mathrm{HO}_{2}$.

$\mathrm{HO} \cdot+\mathrm{H}_{2} \mathrm{O}_{2} \rightarrow \mathrm{HO}_{2} \cdot / \mathrm{O}_{2} \cdot{ }^{-}+\mathrm{H}_{2} \mathrm{O}$

$\mathrm{R} \cdot+\mathrm{O}_{2} \rightarrow \rightarrow \mathrm{R}\left(-\mathrm{H}^{+}\right)+\mathrm{HO}_{2}$

$\mathrm{HO}_{2} / \mathrm{O}_{2}^{-}$. are less reactive than $\cdot \mathrm{OH}$ (Navalon et al., 2010a; Xue et al., 2009a) (Table 1). Some rate constants of $\mathrm{O}_{2}^{-}$ with selected substances are listed in Table 2. In free radical-dominated chain reactions, organic compounds are initially transformed to organic radicals by free radicals, and 
Table 2 - Rate constants of ROS with selected substances.

\begin{tabular}{|c|c|c|c|c|c|c|}
\hline ROS & & Substance & Reaction formula & $\begin{array}{l}\text { Rate constant } \\
(\mathrm{L} /(\mathrm{mol} \cdot \mathrm{sec}))\end{array}$ & $\mathrm{pH}$ & Reference \\
\hline \multirow[t]{24}{*}{. $\mathrm{OH}$} & \multirow{13}{*}{$\begin{array}{l}\text { Inorganic } \\
\text { compounds }\end{array}$} & $\mathrm{H}_{2} \mathrm{PO}_{4}^{-}$ & $\mathrm{H}_{2} \mathrm{PO}_{4}^{-}+. \mathrm{OH} \rightarrow \mathrm{HPO}_{4}^{-}+\mathrm{H}_{2} \mathrm{O}$ & $2 \times 10^{4}$ & $\rho^{\mathrm{b}}$ & (Lipczynskakochany et al., 1995) \\
\hline & & $\mathrm{HPO}_{4}^{2-}$ & $\mathrm{HPO}_{4}^{2-}+. \mathrm{OH} \rightarrow \mathrm{HPO}_{4}^{-}+\mathrm{OH}^{-}$ & $6 \times 10^{5}$ & $7-8.5$ & (Lipczynskakochany et al., 1995) \\
\hline & & $\mathrm{PO}_{4}^{3-}$ & $\mathrm{PO}_{4}^{3-}+. \mathrm{OH} \rightarrow \mathrm{PO}_{4}^{2-}+\mathrm{OH}^{-}$ & $7 \times 10^{6}$ & 11.2 & (Lipczynskakochany et al., 1995) \\
\hline & & $\mathrm{HCO}_{3}^{-}$ & $\mathrm{HCO}_{3}^{-}+. \mathrm{OH} \rightarrow \mathrm{CO}_{3}^{-}+\mathrm{H}_{2} \mathrm{O}$ & $5.7 \times 10^{6}$ & 8.5 & (Lipczynskakochany et al., 1995) \\
\hline & & $\mathrm{CO}_{3}^{2-}$ & $\mathrm{CO}_{3}^{2-}+. \mathrm{OH} \rightarrow \mathrm{CO}_{3 .}^{-}+\mathrm{OH}^{-}$ & $4 \times 10^{8}$ & $10-11$ & (Lipczynskakochany et al., 1995) \\
\hline & & $\mathrm{SO}_{4}^{2-}$ & / & $2 \times 10^{2}$ & $>2$ & (Hanna et al., 2010) \\
\hline & & $\mathrm{I}^{-}$ & $\mathrm{I}^{-}+. \mathrm{OH}_{\mathrm{s}} \rightarrow \mathrm{I} .+\mathrm{OH}_{\mathrm{s}}^{-\mathrm{a}}$ & $1.2 \times 10^{10}$ & l & (Martin et al., 1995) \\
\hline & & $\mathrm{I}_{2}$ & $\mathrm{I}_{2}+. \mathrm{OH}_{\mathrm{s}} \rightarrow \mathrm{I} .+\mathrm{HOI}$ & $1.1 \times 10^{10}$ & l & (Martin et al., 1995) \\
\hline & & $\mathrm{Cl}^{-}$ & $\mathrm{Cl}^{-}+. \mathrm{OH} \rightarrow . \mathrm{ClOH}^{-}$ & $\begin{array}{l}8.9 \times 10^{7}- \\
6.4 \times 10^{8}\end{array}$ & $1-2.5$ & (Lipczynskakochany et al., 1995) \\
\hline & & $\mathrm{ClO}_{3}^{-}$ & $\mathrm{ClO}_{3}^{-}+. \mathrm{OH} \rightarrow \mathrm{ClO}_{3}+\mathrm{OH}^{-}$ & $<1 \times 10^{6}$ & / & (Martin et al., 1995) \\
\hline & & $\mathrm{Br}^{-}$ & $\mathrm{Br}^{-}+. \mathrm{OH} \rightarrow . \mathrm{BrOH}^{-}$ & $3.9 \times 10^{9}$ & 7 & (Farhataziz and Ross, 1977) \\
\hline & & $\mathrm{NO}_{2}^{-}$ & $\mathrm{NO}_{2}^{-}+. \mathrm{OH} \rightarrow \mathrm{NO}_{2 .}+\mathrm{OH}^{-}$ & $8.1 \times 10^{9}$ & 9 & (Farhataziz and Ross, 1977) \\
\hline & & $\mathrm{H}_{2} \mathrm{O}_{2}$ & $\mathrm{H}_{2} \mathrm{O}_{2}+. \mathrm{OH} \rightarrow \mathrm{HO}_{2} / \mathrm{O}_{2}^{-}+\mathrm{H}_{2} \mathrm{O}$ & $2.7 \times 10^{7}$ & l & (Buxton et al., 1988) \\
\hline & \multirow{11}{*}{$\begin{array}{l}\text { Organic } \\
\text { compounds }\end{array}$} & Methanol & 1 & $6.02 \times 10^{8}$ & / & (Ravishankara and Davis, 1978) \\
\hline & & Ethanol & / & $1.58 \times 10^{9}$ & / & (Ravishankara and Davis, 1978) \\
\hline & & 2-Propanol & / & $3 \times 10^{9}$ & / & (Hanna et al., 2010) \\
\hline & & $n$-Butanol & / & $4.6 \times 10^{9}$ & / & (Andreozzi et al., 1999) \\
\hline & & t-Butanol & / & $0.4 \times 10^{9}$ & / & (Andreozzi et al., 1999) \\
\hline & & Phenol & $\mathrm{C}_{6} \mathrm{H}_{5} \mathrm{OH}+. \mathrm{OH} \rightarrow \mathrm{C}_{6} \mathrm{H}_{5}(\mathrm{OH})_{2}$ & $6.6 \times 10^{9}$ & 7 & (Buxton et al., 1988) \\
\hline & & 4-Chlorophenol & / & $7.6 \times 10^{9}$ & 9 & (Lipczynskakochany et al., 1995) \\
\hline & & Dimethyl sulfoxide (DMSO) & l & $5.8 \times 10^{9}-$ & l & (Farhataziz and Ross, 1977) \\
\hline & & & & $7.0 \times 10^{9}$ & & \\
\hline & & Acetic acid & $\mathrm{CH}_{3} \mathrm{CO}_{2} \mathrm{H}+. \mathrm{OH} \rightarrow . \mathrm{CH}_{2} \mathrm{CO}_{2} \mathrm{H}+\mathrm{H}_{2} \mathrm{O}$ & $1.6 \times 10^{7}$ & l & (Keenan and Sedlak, 2008) \\
\hline & & Benzoic acid & $\mathrm{C}_{6} \mathrm{H}_{5} \mathrm{CO}_{2} \mathrm{H}+. \mathrm{OH} \rightarrow \mathrm{HOC}_{6} \mathrm{H}_{5} \mathrm{CO}_{2} \mathrm{H}$ & $5.9 \times 10^{9}$ & l & (Keenan and Sedlak, 2008) \\
\hline \multirow[t]{4}{*}{$\mathrm{O}_{2} \cdot-$} & & 2-Propanol & / & $1 \times 10^{6}$ & / & (Lipczynskakochany et al., 1995) \\
\hline & & Benzoquinone & / & $9.6 \times 10^{8}$ & 7 & (Farhataziz and Ross, 1977) \\
\hline & & Hydroquinone & / & $(1.6 \pm 0.1) \times 10^{7}$ & 7 & (Farhataziz and Ross, 1977) \\
\hline & & Superoxide dismutase (SOD) & / & $1.8 \times 10^{9}$ & $5.3-9.5$ & (Farhataziz and Ross, 1977) \\
\hline \multirow[t]{9}{*}{$\mathrm{FeO}^{2+}$} & \multirow{3}{*}{$\begin{array}{l}\text { Inorganic } \\
\text { compounds }\end{array}$} & As(III) & $\mathrm{As}(\mathrm{III})+\mathrm{Fe}(\mathrm{IV}) \rightarrow \mathrm{As}(\mathrm{IV})+\mathrm{Fe}^{3+}$ & $\sim 10^{6}$ & $\sim 7$ & (Hug and Leupin, 2003) \\
\hline & & $\mathrm{Cl}^{-}$ & I & 100 & 1 & (Jacobsen et al., 1998) \\
\hline & & $\mathrm{NO}_{2}^{-}$ & I & $\leq 10^{5}$ & I & (Jacobsen et al., 1998) \\
\hline & \multirow{6}{*}{$\begin{array}{l}\text { Organic } \\
\text { compounds }\end{array}$} & Methanol & I & $5.74 \times 10^{2}$ & I & (Pestovsky and Bakac, 2008) \\
\hline & & Ethanol & / & $2.5 \times 10^{3}$ & 0 & (Jacobsen et al., 1998) \\
\hline & & Phenol & / & $1.5 \times 10^{4}$ & 0 & (Mártire et al., 2002) \\
\hline & & DMSO & / & $1.26 \times 10^{5}$ & 1 & (Pestovsky and Bakac, 2006) \\
\hline & & Acetic acid & / & 3.1 & 0 & (Jacobsen et al., 1998) \\
\hline & & Benzoic acid & 1 & 80 & 0 & (Jacobsen et al., 1998) \\
\hline
\end{tabular}

further oxidized to carboxylic acids and even $\mathrm{CO}_{2}$. Meanwhile, $\mathrm{HO}_{2} / \mathrm{O}_{2}^{-}$. are reduced to $\mathrm{H}_{2} \mathrm{O}_{2}$, or oxidized to $\mathrm{O}_{2}$.

The half-life of $\mathrm{HO}_{2} / \mathrm{O}_{2}^{-}$. is four orders of magnitude longer than that of .OH (Table 1). The detection methods for $\mathrm{HO}_{2} / \mathrm{O}_{2}^{-}$ are similar to that for .OH. (1) When using DMPO as the spin trap agent, stable ESR spectra of DMPO-OOH/DMPO-O ${ }_{2}^{-}$ adducts can only be obtained in the presence of DMSO (Kohno et al., 1994) or in organic-rich media (Wang et al., 2011). On one hand, the generation rate of DMPO-OOH/ DMPO- $\mathrm{O}_{2}^{-}$adducts is lower than that of DMPO-OH adduct. Alternatively, DMPO-OOH/DMPO- $\mathrm{O}_{2}^{-}$adducts readily decompose to DMPO-OH adduct in aqueous medium (Kohno et al., 1994; Zhao et al., 1998). Hence, the interference from the co-existing . $\mathrm{OH}$ in solution should be eliminated before $\mathrm{HO}_{2} / \mathrm{O}_{2}^{-}$. detection. (2) $\mathrm{HO}_{2} / \mathrm{O}_{2}^{-}$. can also be deduced from the observed scavenging by characteristic quenchers like benzoquinone (Zhang et al., 2012) (Table 2). However, it is almost impossible to distinguish similar organic oxidation products generated by $\mathrm{HO}_{2} / \mathrm{O}_{2}^{-}$. attack from. $\mathrm{OH}$ attack.

\subsection{High-valent iron species}

Some researchers believe that high-valent iron species, i.e., ferryl(IV), are produced in heterogeneous Fenton systems, especially at neutral or basic $\mathrm{pH}$ or in the presence of ligands (Gonzalez-Olmos et al., 2011; Hu et al., 2011; Katsoyiannis et al., 2008; Keenan and Sedlak, 2008; Luo et al., 2010), where high-valent iron is more stable (Diane and Virender, 2008). Though the generation mechanism of surface Fe(IV) (e.g., $\equiv \mathrm{Fe}^{\mathrm{IV}}=\mathrm{O}$ ) in heterogeneous Fenton systems remains unknown, Eq. (6) (Hu et al., 2011; Luo et al., 2010) is sometimes used for illustration. $\mathrm{FeO}^{2+}$ might also be generated from the leached iron-induced homogeneous Fenton reaction, most likely through heterolytic $\mathrm{O}-\mathrm{O}$ bond cleavage by the inner-sphere reaction of $\mathrm{FeOH}^{+}$and $\mathrm{H}_{2} \mathrm{O}_{2}$ (Buda et al., 2001; Remucal and Sedlak, 2011; Li et al., 2010).

$\equiv \mathrm{Fe}^{\mathrm{II}}+\mathrm{H}_{2} \mathrm{O}_{2} \rightarrow \equiv \mathrm{Fe}^{\mathrm{IV}}=\mathrm{O}+\mathrm{H}_{2} \mathrm{O}$ 
High-valent iron is a weaker and more selective oxidant compared to .OH (Table 1). It oxidizes organic compounds probably through one-electron (hydrogen atom transfer, electron transfer) and two-electron (hydride transfer, oxygen atom transfer) pathways, specifically by hydroxylation, methylene ketonization, olefin epoxidation, dehydrogenation, and S-oxygenation etc. (Magario et al., 2012; Mártire et al., 2002; Pestovsky and Bakac, 2008; Pignatello et al., 2006). Some rate constants of $\mathrm{FeO}^{2+}$ with selected substances are listed in Table 2.

Though the half-life of ferryl(IV) in solution is about $0.35 \mathrm{sec}$ (Table 1), calculated from its first-order decay rate constant (2/sec (Bossmann et al., 1998)) at $\mathrm{pH} 3-7$, direct detection of ferryl(IV) is still difficult. (1) Since $\mathrm{FeO}^{2+}$ has a characteristic absorption band, e.g., in the 290-350 $\mathrm{nm}$ range at pH 0 (Mártire et al., 2002), UV-Vis spectroscopy can be used for characterization, if the substrates do not interfere with the absorbance. (2) Resonance Raman spectroscopy and Mössbauer spectroscopy can also detect high-valent iron in solution directly, but only at extremely low temperatures (Nakamoto, 1997; Yurii and Virender, 2008). (3) Since ferryl(IV) can oxidize methanol or ethanol to the corresponding aldehydes, but does not oxidize 2-propanol or aromatic compounds to an appreciable extent (Pham et al., 2009), the respective reactivity with methanol, benzoic acid, and 2-propanol have been used for distinguishing between Fe(IV) and .OH (Keenan and Sedlak, 2008). (4) The kinetic deuterium isotope effect (KDIE) (Gonzalez-Olmos et al., 2011; Pignatello et al., 1999), determined as the ratio of oxidation rates (KDIE $\left.=k_{\mathrm{H}} / k_{\mathrm{D}}\right)$ of the co-existing organic compounds with and without deuterium (like $\mathrm{CH}_{3} \mathrm{OH}$ and $\mathrm{CD}_{3} \mathrm{OH}$ ), may behave differently with ferryl(IV) and .OH, so it can be used as an indicator of ferryl(IV) (detailed below). (5) Olefin epoxidation is uncharacteristic of .OH but is well-known for ferryl complexes (Gonzalez-Olmos et al., 2011). Therefore, it is used as the primary method for ferryl(IV) detection.

Gonzalez-Olmos et al. (2011) compared KDIE for methanol oxidation in an Fe-containing zeolite (Fe-ZSM5) catalyzed heterogeneous Fenton system $(\mathrm{pH} 7)$ with that in a homogeneous Fenton system ( $\mathrm{pH}$ 3). They proposed that an additional oxidant besides. $\mathrm{OH}$ in $\mathrm{Fe}-\mathrm{ZSM} 5 / \mathrm{H}_{2} \mathrm{O}_{2}$ system selectively attacked $\mathrm{C}-\mathrm{H}$ bonds, and could react with t-butanol rather than $\mathrm{HCO}_{3}^{-}$. With the increasing concentration of $\mathrm{HCO}_{3}^{-}$, a 'selective' .OH quencher, KDIE in the $\mathrm{Fe}-\mathrm{ZSM} 5 / \mathrm{H}_{2} \mathrm{O}_{2}$ system increased from 1.33 to 1.41 , similar to that in a ferryl-involved photo-Fenton system, while KDIE decreased with increasing concentration of t-butanol. In a homogeneous Fenton system (the genuine. $\mathrm{OH}$ reaction), KDIE was observed to be 1.07 and unaffected by the presence of scavengers. Moreover, Fe-zeolite catalyzed the epoxidation of cyclohexene by $\mathrm{H}_{2} \mathrm{O}_{2}$, suggesting $\mathrm{Fe}(\mathrm{IV})$ as the additional oxidant.

\section{Interfacial mechanisms of heterogeneous Fenton systems}

Ever since the discovery of heterogeneous Fenton reactions in 1991, Tyre et al. (1991) proposed two possible interfacial mechanisms, i.e., the homogeneous Fenton mechanism induced by surface-leached iron and heterogeneous catalysis on the mineral surface, as illustrated in Fig. 1. However, it is still difficult to distinguish the two mechanisms so far, and both mechanisms may even co-exist.

\subsection{Homogeneous Fenton mechanism induced by surface- leached iron}

In some heterogeneous Fenton systems, certain iron-based materials serve as the source of continuous dissolution of iron especially under acidic $\mathrm{pH}$, which contribute to a homogeneous Fenton reaction-dominated mechanism (Lücking et al., 1998; Matta et al., 2007; Zeng and Lemley, 2009).

Zeng and Lemley (2009) found that about $20 \mathrm{mg} / \mathrm{L}$ ferrous ions desorbed from the prepared $\mathrm{Fe}^{2+}$-substituted ion-exchange resins and played a major role in the degradation of 4,6-dinitro-o-cresol (DNOC) with $\mathrm{H}_{2} \mathrm{O}_{2}$. Addition of either $\mathrm{HCl}$ or $\mathrm{Ca}^{2+}$ promoted the desorption of $\mathrm{Fe}^{2+}$ by ion exchange, thus accelerating the homogeneous oxidation of DNOC. Accordingly, a first-order kinetic model of $\mathrm{Fe}^{2+}$ desorption and second-order oxidation kinetics with respect to. $\mathrm{OH}$ and DNOC were proposed, both of which could simulate the experimental data well.

Lücking et al. (1998) attributed the catalytic activity of iron powder and iron-impregnated activated carbon to leached iron ions. Over $200 \mathrm{mg} / \mathrm{L}$ iron ions leached from iron powder through surface corrosion (Eqs. (7)-(9) (Chu et al., 2012; Joo et al., 2005; Xu and Wang, 2011)) during the oxidation of 4-chlorophenol (4-CP) at initial $\mathrm{pH}$ 5. Iron leaching increased as $\mathrm{pH}$ decreased, accelerating both $\mathrm{H}_{2} \mathrm{O}_{2}$ activation and 4-CP degradation.

$\mathrm{Fe}^{0}+\mathrm{H}_{2} \mathrm{O}_{2}+2 \mathrm{H}^{+} \rightarrow \mathrm{Fe}^{2+}+2 \mathrm{H}_{2} \mathrm{O}$

$\mathrm{Fe}^{0}+\mathrm{O}_{2}+2 \mathrm{H}^{+} \rightarrow \mathrm{Fe}^{2+}+\mathrm{H}_{2} \mathrm{O}_{2}$

$\mathrm{Fe}^{0}+2 \mathrm{H}^{+} \rightarrow \mathrm{Fe}^{2+}+\mathrm{H}_{2}$

$\mathrm{pH}$ influences not only the surface iron leaching process, but also iron speciation and reactivity in the induced homogeneous Fenton reactions. In homogeneous Fenton systems, the reactions between. $\mathrm{OH}$ and organic compounds are usually very fast $\left(k \approx 10^{9}-10^{10} \mathrm{~L} /(\mathrm{mol} \cdot \mathrm{sec})\right)$. Hence, the generation of .OH (Eq. (10) (Pignatello et al., 2006), where $\mathrm{H}_{2} \mathrm{O}$ ligands on $\mathrm{Fe}$ are omitted) becomes the slowest step (Lipczynskakochany et al., 1995), i.e., rate-determining step (RDS). Fe(II) exists predominantly as $\mathrm{Fe}^{2+}$ at $\mathrm{pH}$ below 3 and changes to $\mathrm{Fe}(\mathrm{OH})^{+}$and $\mathrm{Fe}(\mathrm{OH})_{2}$ as $\mathrm{pH}$ increases to 4 (Pignatello et al., 2006). Due to the formation of $\mathrm{Fe}(\mathrm{OH})_{2}$, which is about 10 times more reactive than $\mathrm{Fe}^{2+}$, the generation rate of. $\mathrm{OH}$ increases and reaches a plateau at $\mathrm{pH} 4$ corresponding to a value about 7 times greater than at pH 3 (Pignatello et al., 2006). In addition, Fe(II) also tends to coprecipitate with less Fenton-reactive Fe(III) oxyhydroxides (Eq. (11) (Pignatello et al., 2006)) at pH above 3. Therefore, the optimum $\mathrm{pH}$ of homogeneous Fenton systems is usually 3.

$\mathrm{Fe}(\mathrm{II})+\mathrm{H}_{2} \mathrm{O}_{2} \rightarrow \mathrm{Fe}(\mathrm{III})+\cdot \mathrm{OH}+\mathrm{HO}^{-}$

$k=40-80 \mathrm{~L} /(\mathrm{mol} \cdot \mathrm{sec})$

$\mathrm{Fe}(\mathrm{III})+\mathrm{H}_{2} \mathrm{O}_{2} \rightarrow \mathrm{Fe}(\mathrm{II})+\mathrm{HO}_{2} \cdot+\mathrm{H}^{+}$

$k=2 \times 10^{-3}-2.6 \times 10^{-3} \mathrm{~L} /(\mathrm{mol} \cdot \mathrm{sec})$ 


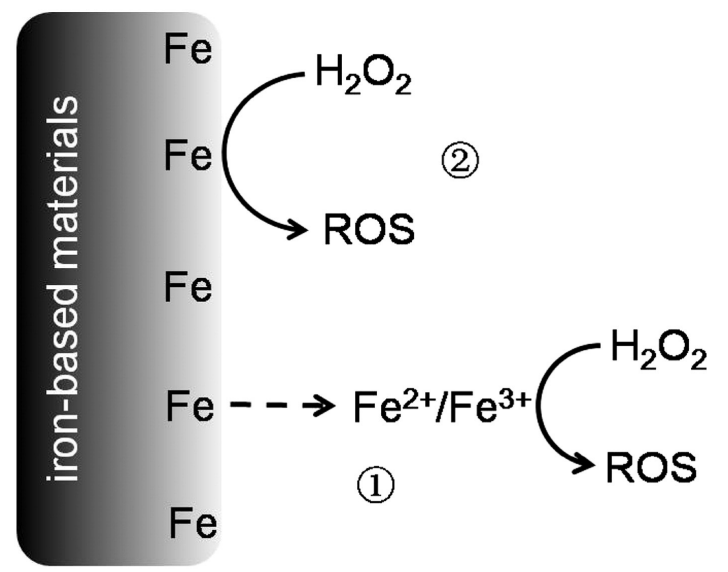

Fig. 1 - Schematic diagram depicting the interfacial mechanisms of heterogeneous Fenton systems catalyzed by iron-based materials: (1) homogeneous Fenton mechanism induced by surface-leached iron and (2) heterogeneous catalysis mechanism. (Surface of iron-based materials in aqueous solution is simplified.)

Moreover, iron-complexing ligands can increase Fe(III) solubility (Remucal and Sedlak, 2011) and broaden the Fenton pH range. A chelating agent may influence the reactivity of iron in at least three ways (He et al., 2015): (i) changing the redox potential of $\mathrm{Fe}^{2+} / \mathrm{Fe}^{3+}$; (ii) creating a labile coordination position on iron ions for complexation with $\mathrm{H}_{2} \mathrm{O}_{2}$, since the complex between $\mathrm{Fe}^{2+}$ and $\mathrm{H}_{2} \mathrm{O}_{2}$ may be a precursor of ROS generation (Pignatello et al., 2006; Remucal and Sedlak, 2011); and (iii) scavenging .OH or generating high-valent iron species (Pignatello et al., 2006).

Admittedly, the proportion of iron leaching-induced homogeneous Fenton mechanism varies for different reaction systems, and cannot be simply determined by the amount of leached iron. For example, Hartmann et al. (2010) suggested that as much as 50-80 mg/L iron ions could start a homogeneous Fenton reaction. However, the research of Kwan and Voelker (2002) showed that $0.34 \mathrm{mg} / \mathrm{L}$ leached $\mathrm{Fe}^{3+}$ already contributed to the overall oxidation of formic acid in the ferrihydrite/ $\mathrm{H}_{2} \mathrm{O}_{2}$ system at $\mathrm{pH} 3$.

\subsection{Heterogeneous catalysis mechanism}

A large number of iron-based materials are stable and undergo limited iron leaching during reactions (Lin and Gurol, 1998; Xue et al., 2009a). Hence, organic compounds are mainly oxidized by the ROS generated from heterogeneous catalysis. Besides, Andreozzi et al. (2002a, 2002b) once proposed a mechanism of non-radical oxidation between adsorbed $\mathrm{H}_{2} \mathrm{O}_{2}$ and adsorbed 3,4-dihydroxybenzoic acid on goethite, probably due to the low goethite loading.

Heterogeneous Fenton reactions are usually controlled by kinetic processes (Lin and Gurol, 1998; Xu and Wang, 2012a) including reactant adsorption, surface chemical reaction and product desorption, due to the fast diffusion process. The kinetic expressions vary according to different RDS.

The rate of catalytic $\mathrm{H}_{2} \mathrm{O}_{2}$ decomposition on the goethite surface is found to be proportional to the surface area of goethite and the concentration of $\mathrm{H}_{2} \mathrm{O}_{2}$ (Huang et al., 2001; Kwan and Voelker, 2003; Lin and Gurol, 1998). Therefore, a mechanism of $\mathrm{H}_{2} \mathrm{O}_{2}$ decomposition based on surface complexation chemistry was proposed by Lin and Gurol (1998) and is widely accepted. Briefly, $\mathrm{H}_{2} \mathrm{O}_{2}$ complexes with the goethite surface ( $\left.\equiv \mathrm{Fe}^{\mathrm{III}}-\mathrm{OH}\right)$ to form a precursor surface complex, $\left(\mathrm{H}_{2} \mathrm{O}_{2}\right)_{\mathrm{s}}$ (Eq. (12)). The electron transfer from ligand-to-metal within the complex produces a transitional state for the surface site $\left(\equiv \mathrm{Fe}^{\mathrm{II}} \cdot \mathrm{O}_{2} \mathrm{H}\right)$ (Eq. (13)), which is deactivated through the dissociation of the peroxide radical (Eq. (14)). Then the produced surface $\equiv \mathrm{Fe}^{\mathrm{II}}$ catalyzes the generation of .OH (Eq. (1)). Free radicals may be consumed by surface sites (Eqs. (15)-(16)) and by adsorbed $\mathrm{H}_{2} \mathrm{O}_{2}$ (Eqs. (17)-(18)), and even be terminated by reacting with each other (Eqs. (19)-(20)). Since $\equiv F e^{\mathrm{III}}-\mathrm{OH}$ and $\equiv \mathrm{Fe}^{\mathrm{III}}$ cycle on the surface, goethite acts as a heterogeneous catalyst. Based on the above elementary reaction steps, a decomposition rate model that resembles the classic Langmuir-Hinshelwood (i.e., the reaction between adsorbed $\mathrm{H}_{2} \mathrm{O}_{2}$ and surface sites) rate expression (Eq. (21) (Lin and Gurol, 1998), where $r_{\mathrm{H}}(\mathrm{mol} /(\mathrm{L} \cdot \mathrm{min}))$ represents $\mathrm{H}_{2} \mathrm{O}_{2}$ decomposition rate, $\left[\mathrm{H}_{2} \mathrm{O}_{2}\right](\mathrm{mol} / \mathrm{L})$ and $[\mathrm{FeOOH}](\mathrm{mol} / \mathrm{L})$ represent the concentration of $\mathrm{H}_{2} \mathrm{O}_{2}$ and $\mathrm{FeOOH}$, respectively, $t$ (min) represents time, $k(\mathrm{~L} /(\mathrm{mol} \cdot \mathrm{min}))$ and $\mathrm{K}_{\mathrm{H}}(\mathrm{L} / \mathrm{mol})$ represent the rate and binding constants, respectively) was obtained and could fit the experimental data well. Hence, the proposed mechanism of $\mathrm{H}_{2} \mathrm{O}_{2}$ surface decomposition was confirmed. However, more direct and conclusive interface evidence is still needed.

$$
\begin{aligned}
& \equiv \mathrm{Fe}-\mathrm{III}-\mathrm{OH}+\mathrm{H}_{2} \mathrm{O}_{2} \leftrightarrow\left(\mathrm{H}_{2} \mathrm{O}_{2}\right)_{\mathrm{s}} \\
& \left(\mathrm{H}_{2} \mathrm{O}_{2}\right)_{\mathrm{s}} \leftrightarrow\left(\equiv \mathrm{Fe}^{\mathrm{II}} \cdot \mathrm{O}_{2} \mathrm{H}\right)+\mathrm{H}_{2} \mathrm{O} \\
& \left(\equiv \mathrm{Fe}^{\mathrm{II}} \cdot \mathrm{O}_{2} \mathrm{H}\right) \rightarrow \equiv \mathrm{Fe}^{\mathrm{II}}+\mathrm{HO}_{2} \cdot \\
& \equiv \mathrm{Fe}^{\mathrm{II}}+\mathrm{H}_{2} \mathrm{O}_{2} \rightarrow \equiv \mathrm{Fe}^{\mathrm{III}}-\mathrm{OH}+\cdot \mathrm{OH} \\
& \mathrm{HO}_{2} \cdot \leftrightarrow \mathrm{H}^{+}+\mathrm{O}_{2} \cdot{ }^{-} \quad p K_{\mathrm{a}}=4.85 \pm 0.1 \\
& \equiv \mathrm{Fe}^{\mathrm{III}}-\mathrm{OH}_{+}+\mathrm{HO}_{2} \cdot / \mathrm{O}_{2} \cdot \cdot^{-} \rightarrow \equiv \mathrm{Fe}^{\mathrm{II}}+\mathrm{H}_{2} \mathrm{O} / \mathrm{OH}^{-}+\mathrm{O}^{2} \\
& \cdot \mathrm{OH}_{+} \equiv \mathrm{Fe}^{\mathrm{II}} \rightarrow \equiv \mathrm{Fe}^{\mathrm{III}}-\mathrm{OH} \\
& \cdot \mathrm{OH}_{+}\left(\mathrm{H}_{2} \mathrm{O}_{2}\right)_{\mathrm{s}} \rightarrow \equiv \mathrm{Fe}^{\mathrm{III}}-\mathrm{OH}+\mathrm{HO}_{2} \cdot+\mathrm{H}_{2} \mathrm{O} \\
& \left(\mathrm{H}_{2} \mathrm{O}_{2}\right)_{\mathrm{s}}+\mathrm{HO}_{2} \cdot / \mathrm{O}_{2} \cdot{ }^{-} \rightarrow \equiv \mathrm{Fe}^{\mathrm{III}}-\mathrm{OH}_{+} \mathrm{H}_{2} \mathrm{O} / \mathrm{OH}^{-}+\cdot \mathrm{OH}+\mathrm{O}_{2} \\
& \mathrm{HO}_{2} \cdot+\mathrm{HO}_{2} \cdot \rightarrow\left(\mathrm{H}_{2} \mathrm{O}_{2}\right)_{\mathrm{s}}+\mathrm{O}_{2} \\
& \cdot \mathrm{OH}+\mathrm{HO}_{2} \cdot / \mathrm{O}_{2} \cdot \cdot^{-} \rightarrow \mathrm{H}_{2} \mathrm{O}+\mathrm{O}_{2} \\
& -\mathrm{r}_{\mathrm{H}}=-\frac{d\left[\mathrm{H}_{2} \mathrm{O}_{2}\right]}{d t}=\frac{k[\mathrm{FeOOH}]\left[\mathrm{H}_{2} \mathrm{O}_{2}\right]}{1+\mathrm{K}_{\mathrm{H}}\left[\mathrm{H}_{2} \mathrm{O}_{2}\right]}
\end{aligned}
$$

In addition, $\mathrm{H}_{2} \mathrm{O}_{2}$ can undergo non-productive disproportionation to $\mathrm{O}_{2}$ and $\mathrm{H}_{2} \mathrm{O}$ at the surface (Kwan and Voelker, 2002; Ortiz de la Plata et al., 2010) (e.g., reaction with oxygen vacancies on the surface (Oliveira et al., 2008) as detailed in Section 3.3) and scavenging of the generated ROS (Xu and Wang, 2012a, 2012b; Xue et al., 2009a) (Eq. (4) and Table 2), both of which reduce the utilization efficiency of $\mathrm{H}_{2} \mathrm{O}_{2}$ in the oxidation reactions.

Once organic compounds are present, $\mathrm{H}_{2} \mathrm{O}_{2}$ decomposition is affected in different ways. The consumption of ROS by organic compounds can promote the productive surface decomposition of $\mathrm{H}_{2} \mathrm{O}_{2}$ (Navalon et al., 2010b), and compete with the scavenging of ROS by $\mathrm{H}_{2} \mathrm{O}_{2}$ as well (Eqs. (4), (17)-(18)) (Costa et al., 2003; Zhang et al., 2012). Some adsorbed organic 
compounds may also compete with $\mathrm{H}_{2} \mathrm{O}_{2}$ for surface active sites (Lücking et al., 1998; Oliveira et al., 2007), inhibiting $\mathrm{H}_{2} \mathrm{O}_{2}$ surface decomposition.

However, mechanisms of ROS utilization by organic compounds vary. Some researchers hypothesize that the surface-generated ROS mainly attack the adsorbed organic compounds, i.e., a Langmuir-Hinshelwood mechanism. They ascribe the enhanced degradation of organic compounds by novel iron-based materials to the enrichment of the organic compounds at the surface (Hu et al., 2011; Liang et al., 2012; Yang et al., 2009). Xue et al. (2009a) found that excess adsorbed PCP might compete with $\mathrm{H}_{2} \mathrm{O}_{2}$ for magnetite surface sites, leading to a decreased generation of ROS and thus a decreased oxidation rate. The Langmuir-Hinshelwood model (Eq. (22) (Xue et al., 2009a), where $k_{\text {app }}(\mathrm{hr})$ is the initial pseudo-first-order rate constant, $k_{\text {int }}(\mathrm{mmol} /(\mathrm{L} \cdot \mathrm{hr}))$ and $\mathrm{K}_{\mathrm{S}}(\mathrm{L} /$ $\mathrm{mmol}$ ) are the intrinsic reaction rate constant and the adsorption constant of $\mathrm{PCP}$ over $\mathrm{Fe}_{3} \mathrm{O}_{4}$ surface respectively, $[\mathrm{PCP}]_{\mathrm{i}}(\mathrm{mmol} / \mathrm{L})$ is the initial PCP concentration) could simulate experimental data. Fluoride $\left(\mathrm{F}^{-}\right)$adsorbed on $\mathrm{Fe}_{3} \mathrm{O}_{4}$ and inhibited both $\mathrm{H}_{2} \mathrm{O}_{2}$ decomposition and PCP oxidation, also suggesting the surface reaction mechanism. Moreover, the Raman spectra of the suspension showed the removal of adsorbed PCP during oxidation. Nevertheless, other researchers propose that the surface-generated ROS mainly oxidize the organic compounds in solution, especially for unadsorbed organic compounds (Furman et al., 2009; Liang et al., 2012), i.e., an Eley-Rideal mechanism. He et al. (2014) directly observed that adsorbed catechol or 4-chlorocatechol remained on the nano- $\mathrm{Fe}_{3} \mathrm{O}_{4}$ surface during the oxidation by in-situ flow-cell ATR-FTIR experiments. Hence, ROS was hypothesized to predominantly attack the unadsorbed parent compounds near the interface region. In addition, the generated organic intermediates were also adsorbed on the nano- $\mathrm{Fe}_{3} \mathrm{O}_{4}$ surface, and might affect the catalytic reactivity of $\mathrm{Fe}_{3} \mathrm{O}_{4}$.

$k_{\text {app }}=\frac{k_{\text {int }} K_{\mathrm{s}}}{1+K_{\mathrm{s}}[\mathrm{PCP}]_{\mathrm{i}}}$

Because electrostatic attractions between charged organic compounds and charged iron oxide surfaces are reported to affect organic oxidation reactions (Kwan and Voelker, 2004; Zhang et al., 2010), pH and ion strength may influence the oxidation rates (Kwan and Voelker, 2004). Moreover, both $\mathrm{H}^{+}$and ligands can promote the dissolution of some iron-based materials, inducing a homogeneous Fenton mechanism (He et al., 2015; Sun et al., 2014; Xue et al., 2009c).

\subsection{Heterogeneous reaction-induced homogeneous mechanism}

Some heterogeneous Fenton systems are characterized by a two-stage degradation kinetic process, i.e., an initial slow induction period and a subsequent rapid oxidation period. Researchers postulate the induction period as heterogeneous reactions including surface iron leaching and heterogeneous catalysis, and the second kinetic stage as homogeneous Fenton reactions induced by the leached iron ( $\mathrm{Xu}$ and Wang, 2011, 2012a; Zhou et al., 2008).

$\mathrm{Xu}$ and Wang (2012a) found that the degradation curve of 2,4-dichlorophenol (2,4-DCP) with $\mathrm{Fe}_{3} \mathrm{O}_{4}$ magnetic nanoparticles (MNPs) $/ \mathrm{H}_{2} \mathrm{O}_{2}$ exhibited two-stage first-order kinetics at pH 2 and 3. During the whole oxidation process, $\mathrm{H}_{2} \mathrm{O}_{2}$ was decomposed gradually. In the first stage, iron was dissolved slowly, indicating slow iron leaching and heterogeneous catalysis. Both the activated surface sites of $\mathrm{Fe}_{3} \mathrm{O}_{4}$ MNPs and the concentrated $\mathrm{H}_{2} \mathrm{O}_{2}$ near the surface may scavenge the surface-generated ROS (Eqs. (4), (15)-(16)), leading to the observed slow oxidation. And the activation energy $\left(E_{\mathrm{a}}\right)$ was higher than that of a homogeneous Fenton reaction. In the second stage, iron leached more rapidly. Both the oxidation rate constant and $E_{\mathrm{a}}$ were similar to that of a homogeneous Fenton system. The radical scavenging experiments confirmed that the primary ROS was free .OH in the bulk solution rather than surface-bound $\cdot \mathrm{OH}$. Therefore, two-stage degradation kinetics may suggest a heterogeneous reaction-induced homogeneous mechanism.

\section{Different heterogeneous Fenton systems catalyzed by characteristic iron-based materials}

Iron-based materials possess the advantages of high Fenton activity, low cost, negligible toxicity, and easy recovery (Pereira et al., 2012; Rahim Pouran et al., 2014). Hence, they become a superior type of heterogeneous Fenton catalysts, which can degrade phenolic compounds, dyes, insecticides, etc. efficiently. According to the reactive content and physicochemical properties, iron-based heterogeneous Fenton catalysts are divided into five primary categories, i.e., zero-valent iron, iron minerals and iron (hydr)oxides, multimetallic iron-based materials, supported iron-based materials, and horseradish peroxidase (HRP)-based materials (Table 3).

\subsection{Zero-valent iron (ZVI or $\mathrm{Fe}^{0}$ )}

Though ZVI is commonly used as a reductant $\left(E_{\mathrm{H}}^{0}\left(\mathrm{Fe}^{2+}\right)\right.$ $\left.\mathrm{Fe}^{\mathrm{O}}\right)=-0.447 \mathrm{~V}$ (Vanýsek, 2011)) in permeable reactive barriers, it has been proved to be a highly efficient heterogeneous Fenton catalyst (Lücking et al., 1998; Tang and Chen, 1996; Xu and Wang, 2011; Zhou et al., 2008). Specifically, nanoparticulate ZVI (nZVI) possesses high surface reactivity and has easy access to contaminated zones, even though aggregation may occur. A heterogeneous Fenton system consisting of $0.5 \mathrm{~g} / \mathrm{L} \mathrm{nZVI}$ and $0.003 \mathrm{~mol} / \mathrm{L} \mathrm{H}_{2} \mathrm{O}_{2}$ could completely remove $100 \mathrm{mg} / \mathrm{L}$ of the biocide 4-chloro-3-methyl phenol (CMP) within $15 \mathrm{~min}$ and $63 \%$ of the corresponding total organic carbon (TOC) in $1 \mathrm{hr}$ at pH 6 (Xu and Wang, 2011).

Reductive ZVI is usually corroded through two-electron transfer in the presence of $\mathrm{H}_{2} \mathrm{O}_{2}$ under acidic conditions (Eqs. (7)-(9)). Even dissolved oxygen (DO) can lead to ZVI corrosion and in-situ $\mathrm{H}_{2} \mathrm{O}_{2}$ generation as well (Eq. (8)), which may lead to a Fenton-like reaction (Keenan and Sedlak, 2008). The released $\mathrm{Fe}^{2+}$ ions in $\mathrm{ZVI} / \mathrm{H}_{2} \mathrm{O}_{2}$ systems are responsible for the efficient degradation of organic contaminants through a homogeneous Fenton mechanism at acidic $\mathrm{pH}$, such as $\mathrm{pH} 2$ or 3 (Lücking et al., 1998; Tang and Chen, 1996; Xu and Wang, 2011; Zhou et al., 2008), or a heterogeneous reaction-induced homogeneous mechanism at higher pH, such as pH 4 or 6 (Xu and Wang, 2011; Zhou et al., 2008). In the second stage of the heterogeneous reaction-induced homogeneous mechanism, ZVI continues to dissolve, mostly 
Table 3 - Efficient iron-based heterogeneous Fenton catalysts.

Category

Zero-valent iron

Iron minerals and iron (hydr)oxide

Multimetallic iron-based materials

Supported

iron-based

Carbon-based

materials

Silicate-based materials as support

Organic compound as support
Iron-based heterogeneous Fenton catalysts

Iron powder (Lücking et al., 1998; Tang and Chen, 1996), zero-valent iron (ZVI or Fe ${ }^{0}$ (Zhou et al. 2008), nanoparticulate zero-valent iron (nZVI) (Xu and Wang, 2011).

Magnetite $\left(\mathrm{Fe}_{3} \mathrm{O}_{4}\right.$ ) (Gao et al., 2007; Xu and Wang, 2012a; Xue et al., 2009a, 2009b; Zhang et al., 2009), goethite ( $\alpha$-FeOOH) (Lin and Gurol, 1996; Lu et al., 2002; Ortiz de la Plata et al., 2010), green rust $\left(\mathrm{GR}\left(\mathrm{Cl}^{-}\right), \mathrm{GR}\left(\mathrm{CO}_{3}^{2-}\right), \mathrm{GR}\left(\mathrm{SO}_{4}^{2-}\right)\right.$ ) (Hanna et al., 2010), ferrous hydroxide colloids (Yan et al., 2012), pyrite $\left(\mathrm{FeS}_{2}\right.$ ) (Matta et al., 2007; Zhang et al., 2014), FeS (Chen et al., 2015), limonite (Souza et al., 2009), nanostructured $\delta$-FeOOH (Pinto et al., 2012).

$\mathrm{Fe}_{3} \mathrm{O}_{4}$ /humic acid $\left(\mathrm{Fe}_{3} \mathrm{O}_{4} / \mathrm{HA}\right.$ ) (Niu et al., 2011), prussian blue modified $\gamma-\mathrm{Fe}_{2} \mathrm{O}_{3}$ (PBMNPs) (Wang and Huang, 2011; Zhang et al., 2010), $\mathrm{Fe}^{0} / \mathrm{Fe}_{3} \mathrm{O}_{4}$ (Costa et al., 2008), $\mathrm{FeO}_{\mathrm{x}} \mathrm{H}_{2 \mathrm{x}-3} / \mathrm{Fe}^{0}$ (Nie et al., 2007), iron oxide/ $\mathrm{Fe}^{0}$ (Nie et al., 2008, 2010).

$\mathrm{Fe}_{3-\mathrm{x}} \mathrm{Ti}_{\mathrm{x}} \mathrm{O}_{4}$ (Yang et al., 2009), $\mathrm{Fe}_{3-\mathrm{x}} \mathrm{Cr}_{x} \mathrm{O}_{4}$ (Costa et al., 2006; Liang et al., 2012; Magalhaes et al., 2007), $\mathrm{Fe}_{3-\mathrm{x}} \mathrm{Mn}_{\mathrm{x}} \mathrm{O}_{4}$ (Costa et al., 2006), $\mathrm{Fe}_{3-\mathrm{x}} \mathrm{Co}_{\mathrm{x}} \mathrm{O}_{4}$ (Costa et al., 2006), $\mathrm{FeVO}_{4}$ (Deng et al., 2008), $\mathrm{BiFeO}_{3}$ (Luo et al., 2010), $\mathrm{Fe}_{3} \mathrm{O}_{4} / \mathrm{CeO}_{2}$ (Xu and Wang, 2012b), Nb-substituted goethite (Oliveira et al., 2008), CuFeZSM-5 (Dukkanci et al., 2010), $\mathrm{Fe} / \mathrm{M}-\mathrm{MnO}_{2}$ (Huang et al., 2015), marmatite (Ramirez et al., 2014), natural vanadium-titanium magnetite (Liang et al., 2010).

Fe/activated carbon (Fe/AC) (Duarte et al., 2012), ordered mesoporous carbon supported iron (Fe/OMC) (Duan et al., 2014), magnetite-loaded mesocellular carbonaceous material $\left(\mathrm{Fe}_{3} \mathrm{O}_{4} /\right.$ MSU-F-C) (Chun et al., 2012), iron-doped carbon aerogel (Duarte et al., 2009), iron-impregnated carbon aerogel (Duarte et al., 2009), $\mathrm{Fe}_{3} \mathrm{O}_{4} /$ multi-walled carbon nanotube $\left(\mathrm{Fe}_{3} \mathrm{O}_{4} / \mathrm{MWCNTs}\right)(\mathrm{Hu}$ et al., 2011), $\mathrm{Fe}_{2} \mathrm{O}_{3} / \mathrm{MWCNTs}$ (Liao et al., 2009), $\mathrm{Fe}_{3} \mathrm{O}_{4}$ decorated reduced graphene oxide $\left(\mathrm{Fe}_{3} \mathrm{O}_{4} /\right.$ rGO) (Liu et al., 2013), graphene oxide- $\mathrm{Fe}_{3} \mathrm{O}_{4}\left(\mathrm{GO}^{-} \mathrm{Fe}_{3} \mathrm{O}_{4}\right)$ (Zubir et al., 2015, 2014).

Quartz/magnetite (Hanna et al., 2008), quartz/amorphous iron (III) (Hanna et al., 2008), quartz/ maghemite (Hanna et al., 2008), quartz/goethite (Hanna et al., 2008), iron oxide nanoparticles immobilized in alumina coated mesoporous SBA-15 silica (FeAlSi) (Lim et al., 2006), FeAlSi-ox (Pham et al., 2009), FeSi-ox (Pham et al., 2009), Fe-zeolite (Fe-ZSM5 (Gonzalez-Olmos et al., 2011; Kuznetsova et al., 2004; Makhotkina et al., 2006), Fe-Beta (Gonzalez-Olmos et al., 2011)),

Fe-MCM-41 mesoporous materials (Gokulakrishnan et al., 2009), pillared saponite clay impregnated with Fe(II) acetylacetonate (Herney-Ramirez et al., 2011), Fe-Al pillared clay (Luo et al., 2009), $\gamma$-FeOOH on a brick grain support (Chou and Huang, 1999), natural containing Fe-clay (Djeffal et al., 2014).

$\mathrm{Fe}^{2+}$-substituted ion-exchange resin (Zeng and Lemley, 2009) (detailed in Section 1.1)

HRP immobilized on aluminum-pillared interlayered clay (Al-PILC) (Cheng et al., 2006) through the reduction of $\mathrm{Fe}^{3+}$ (Zhou et al., 2008) (Eq. (23)), which accelerates the regeneration of $\mathrm{Fe}^{2+}$ in the homogeneous Fenton reaction. Meanwhile, a layer of iron oxides, probably lepidocrocite $(\gamma-\mathrm{FeOOH})$ and magnetite $\left(\mathrm{Fe}_{3} \mathrm{O}_{4}\right)$, is formed in the presence of oxygen and covers the ZVI surface (Zhou et al., 2008). Though $\gamma$-FeOOH alone (Chou and Huang, 1999) or $\mathrm{Fe}_{3} \mathrm{O}_{4}$ alone (Xu and Wang, 2012a) has lower catalytic activity than ZVI, the surface pre-oxidized $\mathrm{ZVI}$ by $\mathrm{H}_{2} \mathrm{SO}_{4}$ showed higher reactivity than fresh ZVI (Xu and Wang, 2011). Therefore, the stability and reusability of ZVI need to be further evaluated.

$2 \mathrm{Fe}^{3+}+\mathrm{Fe}^{0} \rightarrow 3 \mathrm{Fe}^{2+}$

. $\mathrm{OH}$ is the dominant ROS in ZVI-catalyzed heterogeneous Fenton systems, while high-valent iron (Eq. (24)) and DO may also play a role (Keenan and Sedlak, 2008; Xu and Wang, 2011; Zhou et al., 2008). Xu and Wang (2011) found that .OH was responsible for $79 \%$ of CMP removal, and surface-bound .OH accounted for $57 \%$, according to radical-scavenging experiments. They also speculated the remaining $21 \%$ of CMP removal by Fe(IV) attack. Zhou et al. (2008) found that the low concentration of 4-chlorocatechol, which was the oxidation product by. $\mathrm{OH}$ attack, could not explain the rapid 4-CP degradation, and thus proposed another DO-involved organic radical mechanism.

$\mathrm{Fe}^{2+}+\mathrm{H}_{2} \mathrm{O}_{2} \rightarrow \mathrm{Fe}(\mathrm{IV})+\mathrm{H}_{2} \mathrm{O}$.

\subsection{Iron minerals and iron (hydr)oxides}

\subsubsection{Magnetite $\left(\mathrm{Fe}_{3} \mathrm{O}_{4}\right)$}

$\mathrm{Fe}_{3} \mathrm{O}_{4}$ is the only pure iron oxide having mixed valences. Surface structural $\mathrm{Fe}$ (II) is crucial for. $\mathrm{OH}$ generation as discussed in Section 2.2. $\mathrm{Fe}_{3} \mathrm{O}_{4}$ is usually represented by the formula $\left(\mathrm{Fe}^{3+}\right)_{\text {tet }}\left[\mathrm{Fe}^{3+} \mathrm{Fe}^{2+}\right]_{\mathrm{oct}} \mathrm{O}_{4}$, i.e., with $\mathrm{Fe}$ (III) in tetrahedral sites and both $\mathrm{Fe}(\mathrm{II})$ and $\mathrm{Fe}(\mathrm{III})$ in octahedral sites, which can be characterized by Mössbauer spectroscopy. The two valence states on octahedral sites are not distinguishable due to fast electron hopping (Xue et al., 2009a), which may accelerate the cycling of structural Fe(II)/Fe(III). Therefore, Gao et al. (2007) first reported the intrinsic peroxidase-like activity of ferromagnetic $\mathrm{Fe}_{3} \mathrm{O}_{4}$, which was then applied as an efficient heterogeneous Fenton catalyst, mainly catalyzing the generation of .OH (Eq. (1)).

Compared to $\mathrm{ZVI}, \mathrm{Fe}_{3} \mathrm{O}_{4}$ undergoes less iron leaching but requires more $\mathrm{H}_{2} \mathrm{O}_{2}$ and longer reaction time. Even the highly efficient $\mathrm{Fe}_{3} \mathrm{O}_{4} \mathrm{MNPs}$, which exhibit superparamagnetism and uniform redispersion, consume ten times more $\mathrm{H}_{2} \mathrm{O}_{2}$ than nZVI (Xu and Wang, 2011, 2012a). In addition, it commonly needs hours to remove the parent organics.

$\mathrm{pH}$ may influence the interfacial mechanism of $\mathrm{Fe}_{3} \mathrm{O}_{4}$ catalyzed heterogeneous Fenton systems due to $\mathrm{Fe}_{3} \mathrm{O}_{4}$ dissolution. At neutral $\mathrm{pH}, \mathrm{Fe}_{3} \mathrm{O}_{4}$ (MNPs) exhibit excellent stability and reusability (Xue et al., 2009a; Zhang et al., 2009), following a heterogeneous catalysis mechanism as discussed in Section 2.2. At the acidic $\mathrm{pH}$ of 3 , the two-stage degradation kinetics of 
2,4-DCP suggested a heterogeneous reaction-induced homogeneous mechanism (detailed in Section 2.3) (Xu and Wang, 2012a). Meanwhile, the activity of $\mathrm{Fe}_{3} \mathrm{O}_{4}$ MNPs decreased gradually during consecutive runs, probably due to the leached iron and other factors, like the poisoning of the active catalytic sites by adsorbed organic species or oxidation of the surface (He et al., 2014) etc.

\subsubsection{Goethite $(\alpha-\mathrm{FeOOH})$}

Goethite is one of the most thermodynamically stable iron oxides at ambient temperature, with large surface area (100-200 $\left.\mathrm{m}^{2} / \mathrm{g}\right)$, and was the primary iron oxide studied as an efficient heterogeneous Fenton catalyst.

In the heterogeneous Fenton systems, goethite usually undergoes iron leaching through surface reactions. The oxidation of 2-chlorophenol (2-CP) in goethite $/ \mathrm{H}_{2} \mathrm{O}_{2}$ at $\mathrm{pH} 3$ followed the heterogeneous reaction-induced homogeneous mechanism (Lu et al., 2002; Ortiz de la Plata et al., 2010). Proton-promoted dissolution of goethite (Eq. (25) (Lu et al., 2002)) initiated a $\mathrm{Fe}^{3+}$-induced homogeneous Fenton-like reaction. As the degradation of organic compounds proceeded, some reductive byproducts, such as catechol, ascorbate, and chlorohydroquinone, promoted a reductive dissolution of goethite, producing more reactive $\mathrm{Fe}^{2+}$. Meanwhile, they could also enhance the regeneration of $\mathrm{Fe}^{2+}$ by reducing $\mathrm{Fe}^{3+}$ in solution, accelerating the homogeneous Fenton reaction. Even after the removal of $2-\mathrm{CP}, \mathrm{Fe}^{3+}$ may continue to leach by non-reductive dissolution with byproducts like oxalic acid.

$\alpha-\mathrm{FeOOH}+3 \mathrm{H}^{+} \rightarrow \mathrm{Fe}^{3+}+2 \mathrm{H}_{2} \mathrm{O}$

However, goethite shows low solubility in other cases. For example, no dissolved iron was detected in the oxidation of n-butyl chloride at $\mathrm{pH} 7.5$, and the oxidation rate was independent of $\mathrm{pH}$ (5-9) and alkalinity conditions. Hence, a heterogeneous catalysis mechanism was suggested (Lin and Gurol, 1996).

\subsubsection{Other iron minerals and iron (hydr)oxides}

Other iron minerals and iron (hydr)oxides including naturally existing pyrite (Matta et al., 2007), green rust (Hanna et al., 2010), limonite (Souza et al., 2009) and synthesized ferrous hydroxide colloids (Yan et al., 2012), nano $\delta$-FeOOH (Pinto et al., 2012), $\mathrm{Fe}_{3} \mathrm{O}_{4} /$ HA (Niu et al., 2011), PBMNPs (Wang and Huang, 2011; Zhang et al., 2010), Fe/iron oxide (Costa et al., 2008; Nie et al., 2008, 2010), etc., are effective heterogeneous Fenton catalysts. Due to the low iron leaching and the limited reactivity of the reaction filtrate, most of the reaction systems follow the heterogeneous catalysis mechanism. Pyrite $\left(\mathrm{FeS}_{2}\right)$, however, can react with $\mathrm{H}_{2} \mathrm{O}_{2}$ and leaches $\mathrm{Fe}^{3+}$, which is then reduced to $\mathrm{Fe}^{2+}$ by $\mathrm{FeS}_{2}$, leading to the homogeneous Fenton mechanism.

Structural Fe(II) has been found to have higher reactivity towards $\mathrm{H}_{2} \mathrm{O}_{2}$ decomposition than structural $\mathrm{Fe}(\mathrm{III})$, which contributes to the accelerated oxidation of organic compounds (Costa et al., 2006; Hanna et al., 2010; Xue et al., 2009b; Yan et al., 2012), similar to the situation of a homogeneous Fenton system (Eqs. (10)-(11)). Hanna et al. (2010) found that the reactivity of $\mathrm{GR}\left(\mathrm{Cl}^{-}\right)$was higher than that of $\mathrm{GR}\left(\mathrm{SO}_{4}^{2-}\right)$ or $\mathrm{GR}\left(\mathrm{CO}_{3}^{2-}\right)$ due to the higher structural Fe(II)/Fe(III) ratio.

Hence, accelerating the electron transfer from Fe(III) to Fe(II) on iron (hydr)oxides surfaces can greatly enhance the catalytic activity (Costa et al., 2008; Nie et al., 2007, 2008, 2010; $\mathrm{Niu}$ et al., 2011; Zhang et al., 2010). For example, $\mathrm{Fe}_{3} \mathrm{O}_{4} / \mathrm{HA}$ showed better catalytic activity than $\mathrm{Fe}_{3} \mathrm{O}_{4}$, probably due to the higher reduction potential of complexed $\mathrm{Fe}(\mathrm{III})-\mathrm{HA} / \mathrm{Fe}(\mathrm{II})-$ $\mathrm{HA}$, which could contribute to the rapid regeneration of $\mathrm{Fe}(\mathrm{II})$ (Niu et al., 2011). $\mathrm{Fe}^{0} / \mathrm{Fe}_{3} \mathrm{O}_{4}$ possessed higher activity than pure $\mathrm{Fe}^{0}$ or $\mathrm{Fe}_{3} \mathrm{O}_{4}$, due to the electron transfer from $\mathrm{Fe}^{0}$ to magnetite $\mathrm{Fe}$ (III) (Eq. (26)) (Costa et al., 2008), which was also proved by the $\mathrm{OH}$ formation in $\mathrm{Fe}^{\mathrm{O}}$ /iron oxide suspensions (Nie et al., 2008).

$\mathrm{Fe}^{0}+2 \mathrm{Fe}(\mathrm{III})_{\text {magnetite }} \rightarrow 3 \mathrm{Fe}(\mathrm{II})_{\text {magnetite }}$

Aside from the redox action of surface Fe(II)/Fe(III), porous ferrous hydroxide colloid (Fe-colloid I) may generate. $\mathrm{OH}$ from direct homolysis of the adsorbed $\mathrm{H}_{2} \mathrm{O}_{2}$ at caged active sites on the surface, since Fe-colloid II with no pores exhibited lower activity (Yan et al., 2012). Though some researchers (Luo et al., 2010) agreed with this hypothesis, more experimental evidence is still needed.

\subsection{Multimetallic iron-based materials}

Incorporating other metals into iron-based materials can effectively enhance the reactivity towards the productive decomposition of $\mathrm{H}_{2} \mathrm{O}_{2}$ and the oxidation of organic compounds (Costa et al., 2006; Deng et al., 2008; Xu and Wang, 2012b), through varied mechanisms.

Though the interfacial electron transfers between the added metals and iron are very fast and hard to observe, they are believed to cause the observed high catalytic reactivity. The oxidation of $\mathrm{Fe}(\mathrm{II})$ can be accelerated by thermodynamically favorable coupling reactions with metals like Ce(IV), Co(III), Mn (III) or V(V) (Costa et al., 2006; Xu and Wang, 2012b). Meanwhile, the corresponding reduced metals (i.e., Ce(III), Co(II), $\mathrm{Mn}$ (II) or V(IV)) can also activate $\mathrm{H}_{2} \mathrm{O}_{2}$ decomposition (Costa et al., 2006; Deng et al., 2008; Xu and Wang, 2012b), contributing to an enhanced interfacial .OH generation (Fig. 2). Xu and Wang (2012b) confirmed the generation of Ce(III) from Ce(IV) and the oxidation of $\mathrm{Fe}$ (II) to $\mathrm{Fe}$ (III) on the surface of $\mathrm{Fe}_{3} \mathrm{O}_{4} / \mathrm{CeO}_{2}$ from XPS spectra. They also found that $\mathrm{CeO}_{2}$ facilitated the dissolution of iron, inducing a homogeneous Fenton reaction. Hence, the high reactivity of $\mathrm{Fe}_{3} \mathrm{O}_{4} / \mathrm{CeO}_{2}$ was attributed to both the enhanced heterogeneous catalysis and homogeneous reactions.

On the other hand, $\mathrm{Fe}_{3-x} \mathrm{Cr}_{x} \mathrm{O}_{4}$ exhibited high reactivity, probably due to the enhanced regeneration of $\mathrm{Fe}(\mathrm{II})$ by the coupled oxidation of Cr(II) (Eq. (27)) (Magalhaes et al., 2007). In addition, similar to the substitution of octahedral Fe(II) by $\mathrm{Co}(\mathrm{II})$ or $\mathrm{Mn}$ (II) (Costa et al., 2006), $\mathrm{Cr}$ (III) substituted for octahedral $\mathrm{Fe}(\mathrm{III})$ of $\mathrm{Fe}_{3} \mathrm{O}_{4}$ for valence balance. The increased surface area and surface hydroxyl groups might also contribute to the high efficiency of $\mathrm{Fe}_{3-\mathrm{x}} \mathrm{Cr}_{x} \mathrm{O}_{4}$.

$\mathrm{Fe}(\mathrm{III})+\mathrm{Cr}(\mathrm{II}) \rightarrow \mathrm{Fe}(\mathrm{II})+\mathrm{Cr}(\mathrm{III})$

When $\mathrm{Nb}^{5+}$ was inserted into goethite, oxygen vacancy sites were formed in the goethite structure, according to the Mössbauer spectra (Oliveira et al., 2008). Since none of the. $\mathrm{OH}$ scavengers could inhibit $\mathrm{H}_{2} \mathrm{O}_{2}$ decomposition, $\mathrm{H}_{2} \mathrm{O}_{2}$ probably reacted with the surface oxygen vacancies ([] $\left.]_{\text {surf }}\right)$, generating 
adsorbed oxygen [ $\mathrm{O}_{\text {ads }}$, which eventually produced $\mathrm{O}_{2}$ (Eqs. (28)-(29) (Oliveira et al., 2008)). Electrospray ionization coupled with mass spectrometry (ESI-MS) and density functional theory (DFT) calculations also detected other intermediates besides hydroxylation products. Therefore, oxygen vacancy sites participated in the $\mathrm{Nb}$-substituted goethite/ $\mathrm{H}_{2} \mathrm{O}_{2}$ system.

[]$_{\text {surf }}+\mathrm{H}_{2} \mathrm{O}_{2} \rightarrow \mathrm{H}_{2} \mathrm{O}+\left[\mathrm{O}_{\text {ads }}\right]$

$2\left[\mathrm{O}_{\mathrm{ads}}\right] \rightarrow \mathrm{O}_{2}$

\subsection{Supported iron-based materials}

More and more researchers choose carbon materials, like AC, MWCNTs and (r)GO, and silicate materials, like mesoporous silica, quartz, zeolite, and saponite, as the support for efficient heterogeneous Fenton catalysts due to the good chemical stability, high mechanical strength and low cost. Some supports even have large specific surface area $\left(100-1000 \mathrm{~m}^{2} / \mathrm{g}\right)$ and a hydrophobic surface (Hu et al., 2011). Though graphite, AC, and MWCNTs can also catalyze the active decomposition of $\mathrm{H}_{2} \mathrm{O}_{2}$ to a much lower degree (Hu et al., 2011; Lücking et al., 1998), the iron-based material is still the active component of the catalysts.

Some supports can concentrate the organic compounds near the catalytic active center of iron oxides by enhanced adsorption, and thus increase the degradation efficiency (Chun et al., 2012; Hanna et al., 2008; Hu et al., 2011; Liao et al., 2009; Liu et al., 2013; Zubir et al., 2014). Hu et al. (2011) found that more $17 \alpha$-methyltestosterone (MT) was oxidized in the $\mathrm{Fe}_{3} \mathrm{O}_{4} /$ MWCNTs- $\mathrm{H}_{2} \mathrm{O}_{2}$ system than in the $\mathrm{Fe}_{3} \mathrm{O}_{4}-\mathrm{H}_{2} \mathrm{O}_{2}$ system, due to the observed high adsorption of $\mathrm{MT}$ on $\mathrm{Fe}_{3} \mathrm{O}_{4} /$ MWCNTs through hydrophobic interactions. The observed insignificant iron leaching suggested the heterogeneous catalysis mechanism.

Well-dispersed iron oxides on a support can increase the number of active sites for the heterogeneous Fenton reaction, contributing to the high reactivity, though this may lead to iron leaching at acidic pHs as well (Duarte et al., 2009, 2012; Pham et al., 2009). Lim et al. (2006) found higher reactivity for a catalyst prepared by impregnating iron oxide nanoparticles on alumina-coated SBA-15 (FeAlSi) than that of FeSi. TEM images showed iron oxide nanoparticle aggregates on FeSi but not on FeAlSi, and the porosity of FeAlSi was lower than that of the original SBA-15. Both evidences suggested the presence of homogeneously dispersed iron oxide on the pore wall of FeAlSi, which may contribute to the higher reactivity. In addition, the function of $\mathrm{Al}$ on the high reactivity needs further research (Lim et al., 2006; Pham et al., 2009).

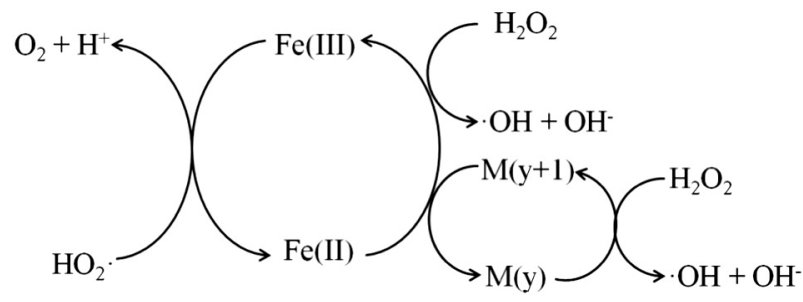

Fig. 2 - Proposed mechanism for the participation of $M$ in heterogeneous Fenton systems: $\mathrm{M}$ (y) represents $\mathrm{Mn}$ (II) or $\mathrm{Co}$ (II) for $\mathrm{Fe}_{3-\mathrm{x}} \mathrm{M}_{\mathrm{x}} \mathrm{O}_{4}$, and $\mathrm{Ce}$ (III) for $\mathrm{Fe}_{3} \mathrm{O}_{4} / \mathrm{CeO}_{2}$.

\subsection{HRP-based materials}

Horseradish peroxidase (HRP) is a heme peroxidase and contains a single protoporphyrin IX heme group with $\mathrm{Fe}(\mathrm{III})$ at the active center in the inactive form (Allen et al., 2009). HRP has good solubility and can effectively catalyze the oxidation of organic compounds, such as phenol (Cooper and Nicell, 1996), bisphenol A (Escalona et al., 2014), 3,3',5,5'-tetramethylbenzidine (Gao et al., 2007), and dyes (de Souza et al., 2007), and even carboxylated single-walled carbon nanotubes (Allen et al., 2009), under neutral $\mathrm{pH}$ with low $\mathrm{H}_{2} \mathrm{O}_{2}$ concentrations (Cheng et al., 2006; Zhang et al., 2009).

Herein, the oxidation of phenol (Allen et al., 2009; Magario et al., 2012) is briefly described as an example of the reaction mechanism of the $\mathrm{HRP} / \mathrm{H}_{2} \mathrm{O}_{2}$ system. First, $\mathrm{H}_{2} \mathrm{O}_{2}$ binds to the heme $\mathrm{Fe}$ (III) of HRP to form a precursor complex, which undergoes protein-assisted heterolytic cleavage and loses a water molecule. Hence, the precursor complex is transformed to Compound I, which is comprised of Fe(IV) and a porphyrin $\pi$ cation radical. Then phenol is oxidized by Compound I to generate phenoxy radical, while Compound I undergoes one-electron reduction to form Compound II, which is still comprised of $\mathrm{Fe}(\mathrm{IV})$ and a porphyrin $\pi$ radical. The formed Compound II can oxidize another phenol to phenoxy radical and regenerates HRP. Phenoxy radicals react to generate dimers, oligomers and polymers with low solubility, which should be further removed by precipitation or filtration. Therefore, the ROS in the $\mathrm{HRP} / \mathrm{H}_{2} \mathrm{O}_{2}$ system is $\mathrm{Fe}(\mathrm{IV})$.

It is noteworthy that HRP is expensive. Both the interaction between the generated free radicals and the active center of HRP and the entrapment of HRP by oligomeric or polymeric products inactivate HRP (Magario et al., 2012). However, the catalytic lifetime of HRP can be extended by recycling through the proper treatment process (Escalona et al., 2014), the use of additives (Magario et al., 2012) and enzyme immobilization (Cheng et al., 2006).

Cheng et al. (2006) found that immobilizing HRP on Al-PILC resulted in good phenol removal with $\mathrm{H}_{2} \mathrm{O}_{2}$ over a broad $\mathrm{pH}$ range (pH 4.5-9.3), and a better storage stability compared to free HRP. The oxidation mechanism of the immobilized $\mathrm{HRP} / \mathrm{H}_{2} \mathrm{O}_{2}$ system was thought to be the same as that of the free $\mathrm{HRP} / \mathrm{H}_{2} \mathrm{O}_{2}$ system. The addition of a highly hydrophilic additive, polyethylene glycol (PEG), could significantly improve the oxidation efficiency. PEG can form a protective layer in the vicinity of the active centers of HRP to restrict the attack of the generated phenoxy radicals. It can also combine with the polymer products to prevent the entrapment of HRP. Nevertheless, the performance of the immobilized HRP decreased markedly after reuse. Hence, the reusability needed to be improved.

\section{Conclusions and perspectives}

Heterogeneous Fenton reactions stand out among various AOPs, due to the structural stability and reusability of the catalysts, wide application $\mathrm{pH}$ range, high oxidation efficiency and low operating costs. Heterogeneous reactions including interfacial $\mathrm{H}_{2} \mathrm{O}_{2}$ decomposition, possible active metal dissolution and organics adsorption, and possible homogeneous Fenton chain reactions contribute to the complex reaction 
mechanisms of heterogeneous Fenton systems. A more comprehensive knowledge of reaction mechanisms will promote the industrial application of such a promising technology.

(1) Some mechanisms of ROS generation, especially, the detailed interfacial electron-transfer processes, remain as basic scientific problems in heterogeneous Fenton chemistry. High-valent iron, whether existing in a surface-bound form or in a freely dissolved form, needs direct detection or even quantification. Whether the decomposed $\mathrm{H}_{2} \mathrm{O}_{2}$ should be pre-complexed to the catalysts surface, and whether the homolytic O-O bond cleavage of $\mathrm{H}_{2} \mathrm{O}_{2}$ involves the redox action of surface $\mathrm{Fe}(\mathrm{II}) /$ $\mathrm{Fe}(\mathrm{III})$, also need direct experimental evidences. The existence and the reaction mechanism of oxygen vacancies in iron-based materials need intensive investigations. Moreover, the mechanisms of ROS utilization are still controversial as mentioned in Section 2.2.

(2) Combinations of various measurement techniques may provide better insights into the reaction mechanisms. Real-time quantification of ROS, isotope tracing techniques, and theoretical chemistry methods can provide more clues to the reaction process. Spectroscopic technologies, especially when connected with in-situ reactions, offer more information on a molecular scale like interfacial changes.

(3) Three primary issues, i.e., the degradation efficiency, the reactivity and stability of the catalyst, and the efficiency of $\mathrm{H}_{2} \mathrm{O}_{2}$ utilization, should be considered simultaneously in designing and applying heterogeneous Fenton systems. Since the pure iron (hydr)oxides suffer from relatively low catalytic reactivity or serious iron leaching, a supported multimetallic iron-based material (e.g., FeCu/HMS (Wang et al., 2015a), CuFe-MC (Wang et al., 2015b), MgO@Fe $\mathrm{O}_{3} /$ KIT-6 (Zheng et al., 2015)) may possess the advantage of low $\mathrm{H}_{2} \mathrm{O}_{2}$ consumption, high catalytic reactivity and good structural stability, thus providing a promising heterogeneous Fenton catalyst.

(4) As for industrial applications, other treatment processes, such as filtration and biological treatment (Melero et al., 2009; Zhang et al., 2011), can be coupled to achieve the recycling of catalysts and complete mineralization of organics. In addition, toxicity tests can be added to evaluate the heterogeneous Fenton process when applied in drinking water treatment.

\section{Acknowledgments}

This work was supported by the National Natural Science Foundation of China (Nos. 21107125, 21577160, 51221892, 51290282 and 41201498).

\section{R E F E R E N C E S}

Allen, B.L., Kotchey, G.P., Chen, Y., Yanamala, N.V.K., Klein-Seetharaman, J., Kagan, V.E., et al., 2009. Mechanistic investigations of horseradish peroxidase-catalyzed degradation of single-walled carbon nanotubes. J. Am. Chem. Soc. 131, 17194-17205.

Andreozzi, R., Caprio, V., Insola, A., Marotta, R., 1999. Advanced oxidation processes (AOP) for water purification and recovery. Catal. Today 53, 51-59.

Andreozzi, R., Caprio, V., Marotta, R., 2002a. Oxidation of 3,4-dihydroxybenzoic acid by means of hydrogen peroxide in aqueous goethite slurry. Water Res. 36, 2761-2768.

Andreozzi, R., D'Apuzzo, A., Marotta, R., 2002b. Oxidation of aromatic substrates in water/goethite slurry by means of hydrogen peroxide. Water Res. 36, 4691-4698.

BaČIĆ, G., MojoviĆ, M., 2005. EPR Spin trapping of oxygen radicals in plants: a methodological overview. Ann. N.Y. Acad. Sci. 1048, 230-243.

Bossmann, S.H., Oliveros, E., Göb, S., Siegwart, S., Dahlen, E.P., Payawan, L., et al., 1998. New evidence against hydroxyl radicals as reactive intermediates in the thermal and photochemically enhanced fenton reactions. J Phys. Chem. A. 102, 5542-5550.

Buda, F., Ensing, B., Gribnau, M.C.M., Baerends, E.J., 2001. DFT study of the active intermediate in the Fenton reaction. Chem. Eur. J. 7, 2775-2783.

Buxton, G.V., Greenstock, C.L., Helman, W.P., Ross, A.B., 1988. Critical review of rate constants for reactions of hydrated electrons, hydrogen atoms and hydroxyl radicals in aqueous solution. J. Phys. Chem. Ref. Data 17, 513-886.

Chen, H., Zhang, Z., Yang, Z., Yang, Q., Li, B., Bai, Z., 2015. Heterogeneous Fenton-like catalytic degradation of 2,4-dichlorophenoxyacetic acid in water with FeS. Chem. Eng. J. $273,481-489$

Cheng, J., Yu, S.M., Zuo, P., 2006. Horseradish peroxidase immobilized on aluminum-pillared interlayered clay for the catalytic oxidation of phenolic wastewater. Water Res. 40, 283-290.

Chou, S.S., Huang, C.P., 1999. Application of a supported iron oxyhydroxide catalyst in oxidation of benzoic acid by hydrogen peroxide. Chemosphere 38, 2719-2731.

Chu, L., Wang, J., Dong, J., Liu, H., Sun, X., 2012. Treatment of coking wastewater by an advanced Fenton oxidation process using iron powder and hydrogen peroxide. Chemosphere 86, 409-414.

Chun, J., Lee, H., Lee, S.H., Hong, S.W., Lee, J., Lee, C., et al., 2012. Magnetite/mesocellular carbon foam as a magnetically recoverable Fenton catalyst for removal of phenol and arsenic. Chemosphere 89, 1230-1237.

Cooper, V.A., Nicell, J.A., 1996. Removal of phenols from a foundry wastewater using horseradish peroxidase. Water Res. 30, 954-964.

Costa, R.C.C., de Fatima, M., Lelis, F., Oliveira, L.C.A., Fabris, J.D., Ardisson, J.D., et al., 2003. Remarkable effect of $\mathrm{Co}$ and $\mathrm{Mn}$ on the activity of $\mathrm{Fe}_{3-\mathrm{x}} \mathrm{M}_{\mathrm{x}} \mathrm{O}_{4}$ promoted oxidation of organic contaminants in aqueous medium with $\mathrm{H}_{2} \mathrm{O}_{2}$. Catal. Commun. 4, 525-529.

Costa, R.C.C., Lelis, M.F.F., Oliveira, L.C.A., Fabris, J.D., Ardisson, J.D., Rios, R., et al., 2006. Novel active heterogeneous Fenton system based on $\mathrm{Fe}_{3-\mathrm{x}} \mathrm{M}_{\mathrm{x}} \mathrm{O}_{4}$ ( $\left.\mathrm{Fe}, \mathrm{Co}, \mathrm{Mn}, \mathrm{Ni}\right)$ : the role of $\mathrm{M}^{2+}$ species on the reactivity towards $\mathrm{H}_{2} \mathrm{O}_{2}$ reactions. J. Hazard. Mater. 129, 171-178.

Costa, R.C.C., Moura, F.C.C., Ardisson, J.D., Fabris, J.D., Lago, R.M., 2008. Highly active heterogeneous Fenton-like systems based on $\mathrm{Fe} / \mathrm{Fe}_{3} \mathrm{O}_{4}$ composites prepared by controlled reduction of iron oxides. Appl. Catal. B-Environ. 83, 131-139.

de Souza, S.M.A.G.U., Forgiarini, E., de Souza, A.A.U., 2007. Toxicity of textile dyes and their degradation by the enzyme horseradish peroxidase (HRP). J. Hazard. Mater. 147, 1073-1078.

Deng, J., Jiang, J., Zhang, Y., Lin, X., Du, C., Xiong, Y., 2008. FeVO4 as a highly active heterogeneous Fenton-like catalyst towards the degradation of Orange II. Appl. Catal. B-Environ. 84, 468-473.

Dhakshinamoorthy, A., Navalon, S., Alvaro, M., Garcia, H., 2012. Metal nanoparticles as heterogeneous Fenton catalysts. ChemSusChem 5, 46-64.

Diane, E.C., Virender, K.S., 2008. Aqueous Ferrate(V) and Ferrate(IV) in Alkaline Medium: Generation and Reactivity. In: 
Virender, K.S. (Ed.), Ferrates. American Chemical Society, Washington, DC, pp. 158-166.

Djeffal, L., Abderrahmane, S., Benzina, M., Fourmentin, M., Siffert, S., Fourmentin, S., 2014. Efficient degradation of phenol using natural clay as heterogeneous Fenton-like catalyst. Environ. Sci. Pollut. Res. 21, 3331-3338.

Duan, F., Yang, Y.Z., Li, Y.P., Cao, H.B., Wang, Y., Zhang, Y., 2014. Heterogeneous Fenton-like degradation of 4-chlorophenol using iron/ordered mesoporous carbon catalyst. J. Environ. Sci. 26, 1171-1179.

Duarte, F., Maldonado-Hodar, F.J., Perez-Cadenas, A.F., Madeira, L.M., 2009. Fenton-like degradation of azo-dye orange II catalyzed by transition metals on carbon aerogels. Appl. Catal. B-Environ. 85, 139-147.

Duarte, F., Maldonado-Hodar, F.J., Madeira, L.M., 2012. Influence of the particle size of activated carbons on their performance as Fe supports for developing Fenton-like catalysts. Ind. Eng. Chem. Res. 51, 9218-9226.

Dukkanci, M., Gunduz, G., Yilmaz, S., Yaman, Y.C., Prikhod'ko, R.V., Stolyarova, I.V., 2010. Characterization and catalytic activity of CuFeZSM-5 catalysts for oxidative degradation of Rhodamine 6G in aqueous solutions. Appl. Catal. B-Environ. 95, 270-278.

Escalona, I., de Grooth, J., Font, J., Nijmeijer, K., 2014. Removal of BPA by enzyme polymerization using NF membranes. J. Membr. Sci. 468, 192-201.

Farhataziz, Ross, A.B., 1977. Selective specific rates of reactions of transients in water and aqueous solutions. Part III. Hydroxyl radical and perhydroxyl radical and their radical ionsNational Standard Reference Data Series. National Bureau of Standards, United States.

Faure, A.M., Andersen, M.L., Nystroem, L., 2012. Ascorbic acid induced degradation of beta-glucan: hydroxyl radicals as intermediates studied by spin trapping and electron spin resonance spectroscopy. Carbohydr. Polym. 87, 2160-2168.

Furman, O., Laine, D.F., Blumenfeld, A., Teel, A.L., Shimizu, K., Cheng, I.F., et al., 2009. Enhanced reactivity of superoxide in water-solid matrices. Environ. Sci. Technol. 43, 1528-1533.

Gao, L.Z., Zhuang, J., Nie, L., Zhang, J.B., Zhang, Y., Gu, N., et al., 2007. Intrinsic peroxidase-like activity of ferromagnetic nanoparticles. Nat. Nanotechnol. 2, 577-583.

Garrido-Ramirez, E.G., Theng, B.K.G., Mora, M.L., 2010. Clays and oxide minerals as catalysts and nanocatalysts in Fenton-like reactions - a review. Appl. Clay Sci. 47, 182-192.

Gokulakrishnan, N., Pandurangan, A., Sinha, P.K., 2009. Catalytic wet peroxide oxidation technique for the removal of decontaminating agents ethylenediaminetetraacetic acid and oxalic acid from aqueous solution using efficient Fenton type Fe-MCM-41 mesoporous materials. Ind. Eng. Chem. Res. 48, 1556-1561.

Gonzalez-Olmos, R., Holzer, F., Kopinke, F.D., Georgi, A., 2011. Indications of the reactive species in a heterogeneous Fenton-like reaction using Fe-containing zeolites. Appl. Catal. AGen. 398, 44-53.

Grebel, J.E., Pignatello, J.J., Mitch, W.A., 2010. Effect of halide ions and carbonates on organic contaminant degradation by hydroxyl radical-based advanced oxidation processes in saline waters. Environ. Sci. Technol. 44, 6822-6828.

Hanna, K., Kone, T., Medjahdi, G., 2008. Synthesis of the mixed oxides of iron and quartz and their catalytic activities for the Fenton-like oxidation. Catal. Commun. 9, 955-959.

Hanna, K., Kone, T., Ruby, C., 2010. Fenton-like oxidation and mineralization of phenol using synthetic $\mathrm{Fe}(\mathrm{II})-\mathrm{Fe}$ (III) green rusts. Environ. Sci. Pollut. Res. 17, 124-134.

Hartmann, M., Kullmann, S., Keller, H., 2010. Wastewater treatment with heterogeneous Fenton-type catalysts based on porous materials. J. Mater. Chem. 20, 9002-9017.

He, J., Yang, X., Men, B., Bi, Z., Pu, Y., Wang, D., 2014. Heterogeneous Fenton oxidation of catechol and 4chlorocatechol catalyzed by nano- $\mathrm{Fe}_{3} \mathrm{O}_{4}$ : role of the interface. Chem. Eng. J. 258, 433-441.
He, J., Yang, X., Men, B., Yu, L., Wang, D., 2015. EDTA enhanced heterogeneous Fenton oxidation of dimethyl phthalate catalyzed by $\mathrm{Fe}_{3} \mathrm{O}_{4}$ : kinetics and interface mechanism. J. Mol. Catal. A-Chem. 408, 179-188.

Herney-Ramirez, J., Silva, A.M.T., Vicente, M.A., Costa, C.A., Madeira, L.M., 2011. Degradation of acid orange 7 using a saponite-based catalyst in wet hydrogen peroxide oxidation: kinetic study with the Fermi's equation. Appl. Catal. B-Environ. 101, 197-205.

Hu, X., Liu, B., Deng, Y., Chen, H., Luo, S., Sun, C., et al., 2011. Adsorption and heterogeneous Fenton degradation of 17 alpha-methyltestosterone on nano $\mathrm{Fe}_{3} \mathrm{O}_{4} /$ MWCNTs in aqueous solution. Appl. Catal. B-Environ. 107, 274-283.

Huang, H.H., Lu, M.C., Chen, J.N., 2001. Catalytic decomposition of hydrogen peroxide and 2-chlorophenol with iron oxides. Water Res. 35, 2291-2299.

Huang, W., Brigante, M., Wu, F., Hanna, K., Mailhot, G., 2013. Effect of ethylenediamine- $\mathrm{N}, \mathrm{N}^{\prime}$-disuccinic acid on Fenton and photo-Fenton processes using goethite as an iron source: optimization of parameters for bisphenol A degradation. Environ. Sci. Pollut. Res. Int. 20, 39-50.

Huang, R., Liu, Y., Chen, Z., Pan, D., Li, Z., Wu, M., et al., 2015. Fe-species-loaded mesoporous $\mathrm{MnO}_{2}$ superstructural requirements for enhanced catalysis. ACS Appl. Mater. Interfaces 7, 3949-3959.

Hug, S.J., Leupin, O., 2003. Iron-catalyzed oxidation of arsenic(III) by oxygen and by hydrogen peroxide: $\mathrm{pH}$-dependent formation of oxidants in the Fenton reaction. Environ. Sci. Technol. 37, 2734-2742.

Jacobsen, F., Holcman, J., Sehested, K., 1998. Reactions of the ferryl ion with some compounds found in cloud water. In. J. Chem. Kinet. 30, 215-221.

Joo, S.H., Feitz, A.J., Sedlak, D.L., Waite, T.D., 2005. Quantification of the oxidizing capacity of nanoparticulate zero-valent iron. Environ. Sci. Technol. 39, 1263-1268.

Katsoyiannis, I.A., Ruettimann, T., Hug, S.J., 2008. PH dependence of Fenton reagent generation and As(III) oxidation and removal by corrosion of zero valent iron in aerated water. Environ. Sci. Technol. 42, 7424-7430.

Keenan, C.R., Sedlak, D.L., 2008. Factors affecting the yield of oxidants from the reaction of nanoparticulate zero-valent iron and oxygen. Environ. Sci. Technol. 42, 1262-1267.

Kitis, M., Kaplan, S.S., 2007. Advanced oxidation of natural organic matter using hydrogen peroxide and iron-coated pumice particles. Chemosphere 68, 1846-1853.

Kohno, M., Mizuta, Y., Kusai, M., Masumizu, T., Makino, K., 1994. Measurements of superoxide anion radical and superoxide anion scavenging activity by electron spin resonance spectroscopy coupled with DMPO spin trapping. Bull. Chem. Soc. Jap. 67, 1085-1090.

Kuznetsova, E.V., Savinov, E.N., Vostrikova, L.A., Parmon, V.N., 2004. Heterogeneous catalysis in the Fenton-type system FeZSM-5/ $\mathrm{H}_{2} \mathrm{O}_{2}$. Appl. Catal. B-Environ. 51, 165-170.

Kwan, W.P., Voelker, B.M., 2002. Decomposition of hydrogen peroxide and organic compounds in the presence of dissolved iron and ferrihydrite. Environ. Sci. Technol. 36, 1467-1476.

Kwan, W.P., Voelker, B.M., 2003. Rates of hydroxyl radical generation and organic compound oxidation in mineral-catalyzed Fenton-like systems. Environ. Sci. Technol. 37, 1150-1158.

Kwan, W.P., Voelker, B.M., 2004. Influence of electrostatics on the oxidation rates of organic compounds in heterogeneous Fenton systems. Environ. Sci. Technol. 38, 3425-3431.

Li, F., England, J., Que, L., 2010. Near-stoichiometric conversion of $\mathrm{H}_{2} \mathrm{O}_{2}$ to $\mathrm{FeIV}=\mathrm{O}$ at a nonheme iron(II) center. insights into the O-O bond cleavage step. J. Am. Chem. Soc. 132, 2134-2135.

Liang, X., Zhong, Y., Zhu, S., Zhu, J., Yuan, P., He, H., et al., 2010. The decolorization of acid orange II in non-homogeneous Fenton reaction catalyzed by natural vanadium-titanium magnetite. J. Hazard. Mater. 181, 112-120. 
Liang, X., Zhong, Y., He, H., Yuan, P., Zhu, J., Zhu, S., et al., 2012. The application of chromium substituted magnetite as heterogeneous Fenton catalyst for the degradation of aqueous cationic and anionic dyes. Chem. Eng. J. 191, 177-184.

Liao, Q., Sun, J., Gao, L., 2009. Degradation of phenol by heterogeneous Fenton reaction using multi-walled carbon nanotube supported $\mathrm{Fe}_{2} \mathrm{O}_{3}$ catalysts. Colloids Surf. A Physicochem. Eng. Asp. 345, 95-100.

Lim, H., Lee, J., Jin, S., Kim, J., Yoon, J., Hyeon, T., 2006. Highly active heterogeneous Fenton catalyst using iron oxide nanoparticles immobilized in alumina coated mesoporous silica. Chem. Commun. 463-465.

Lin, S.S., Gurol, M.D., 1996. Heterogeneous catalytic oxidation of organic compounds by hydrogen peroxide. Water Sci. Technol. 34, $57-64$.

Lin, S.S., Gurol, M.D., 1998. Catalytic decomposition of hydrogen peroxide on iron oxide: kinetics, mechanism, and implications. Environ. Sci. Technol. 32, 1417-1423.

Lipczynskakochany, E., Sprah, G., Harms, S., 1995. Influence of some groundwater and surface waters constituents on the degradation of 4-chlorophenol by the Fenton reaction. Chemosphere 30, 9-20.

Liu, W., Qian, J., Wang, K., Xu, H., Jiang, D., Liu, Q., et al., 2013. Magnetically separable $\mathrm{Fe}_{3} \mathrm{O}_{4}$ nanoparticles-decorated reduced graphene oxide nanocomposite for catalytic wet hydrogen peroxide oxidation. J. Inorg. Organomet. Polym. Mater. 23, 907-916.

Lu, M.C., Chen, J.N., Huang, H.H., 2002. Role of goethite dissolution in the oxidation of 2-chlorophenol with hydrogen peroxide. Chemosphere 46, 131-136.

Lücking, F., Koser, H., Jank, M., Ritter, A., 1998. Iron powder, graphite and activated carbon as catalysts for the oxidation of 4chlorophenol with hydrogen peroxide in aqueous solution. Water Res. 32, 2607-2614.

Luo, M., Bowden, D., Brimblecombe, P., 2009. Catalytic property of Fe-Al pillared clay for Fenton oxidation of phenol by $\mathrm{H}_{2} \mathrm{O}_{2}$. Appl. Catal. B-Environ. 85, 201-206.

Luo, W., Zhu, L., Wang, N., Tang, H., Cao, M., She, Y., 2010. Efficient removal of organic pollutants with magnetic nanoscaled $\mathrm{BiFeO}_{3}$ as a reusable heterogeneous Fenton-like catalyst. Environ. Sci. Technol. 44, 1786-1791.

Machulek, A., Vautier-Giongo, C., Moraes, J.E.F., Nascimento, C.A.O., Quina, F.H., 2006. Laser flash photolysis study of the photocatalytic step of the photo-Fenton reaction in saline solution. Photochem. Photobiol. 82, 208-212.

Magalhaes, F., Pereira, M.C., Botrel, S.E.C., Fabris, J.D., Macedo, W.A., Mendonca, R., et al., 2007. Cr-containing magnetites $\mathrm{Fe}_{3-\mathrm{x}} \mathrm{Cr}_{\mathrm{x}} \mathrm{O}_{4}$ : the role of $\mathrm{Cr}^{3+}$ and $\mathrm{Fe}^{2+}$ on the stability and reactivity towards $\mathrm{H}_{2} \mathrm{O}_{2}$ reactions. Appl. Catal. A-Gen. 332, 115-123.

Magario, I., García Einschlag, F.S., Rueda, E.H., Zygadlo, J., Ferreira, M.L., 2012. Mechanisms of radical generation in the removal of phenol derivatives and pigments using different Fe-based catalytic systems. J. Mol. Catal. A-Chem. 352, 1-20.

Makhotkina, O.A., Kuznetsova, E.V., Preis, S.V., 2006. Catalytic detoxification of 1,1-dimethylhydrazine aqueous solutions in heterogeneous Fenton system. Appl. Catal. B-Environ. 68, 85-91.

Martin, S.T., Lee, A.T., Hoffmann, M.R., 1995. Chemical mechanism of inorganic oxidants in the $\mathrm{TiO}_{2} / \mathrm{UV}$ process: increased rates of degradation of chlorinated hydrocarbons. Environ. Sci. Technol. 29, 2567-2573.

Mártire, D.O., Caregnato, P., Furlong, J., Allegretti, P., Gonzalez, M.C., 2002. Kinetic study of the reactions of oxoiron(IV) with aromatic substrates in aqueous solutions. In. J. Chem. Kinet. 34, 488-494.

Matta, R., Hanna, K., Chiron, S., 2007. Fenton-like oxidation of 2,4,6-trinitrotoluene using different iron minerals. Sci. Total Environ. 385, 242-251.

Melero, J.A., Martinez, F., Botas, J.A., Molina, R., Pariente, M.I., 2009. Heterogeneous catalytic wet peroxide oxidation systems for the treatment of an industrial pharmaceutical wastewater. Water Res. 43, 4010-4018.
Mesquita, I., Matos, L.C., Duarte, F., Maldonado-Hodar, F.J., Mendes, A., Madeira, L.M., 2012. Treatment of azo dye-containing wastewater by a Fenton-like process in a continuous packed-bed reactor filled with activated carbon. J. Hazard. Mater. 237, 30-37.

Nakamoto, K., 1997. Structure, spectra and biological significance of high-valent iron(IV,V) porphyrins. J. Mol. Struct. 408, 11-16.

Navalon, S., Alvaro, M., Garcia, H., 2010a. Heterogeneous Fenton catalysts based on clays, silicas and zeolites. Appl. Catal. B-Environ. 99, 1-26.

Navalon, S., Martin, R., Alvaro, M., Garcia, H., 2010b. Gold on diamond nanoparticles as a highly efficient Fenton catalyst. Angew. Chem.-Int. Edit. 49, 8403-8407.

Nidheesh, P.V., 2015. Heterogeneous Fenton catalysts for the abatement of organic pollutants from aqueous solution: a review. RSC Adv. 5, 40552-40577.

Nie, Y., Hu, C., Qu, J., Zhou, L., Hu, X., 2007. Photoassisted degradation of azodyes over $\mathrm{FeO}_{\mathrm{x}} \mathrm{H}_{2 \mathrm{x}-3} / \mathrm{Fe}^{0}$ in the presence of $\mathrm{H}_{2} \mathrm{O}_{2}$ at neutral $\mathrm{pH}$ values. Environ. Sci. Technol. 41, 4715-4719.

Nie, Y., Hu, C., Zhou, L., Qu, J., 2008. An efficient electron transfer at the $\mathrm{Fe}$ /iron oxide interface for the photoassisted degradation of pollutants with $\mathrm{H}_{2} \mathrm{O}_{2}$. Appl. Catal. B-Environ. 82, 151-156.

Nie, Y., Hu, C., Zhou, L., Qu, J., Wei, Q., Wang, D., 2010. Degradation characteristics of humic acid over iron oxides $/ \mathrm{Fe}^{0}$ core-shell nanoparticles with UVA/ $\mathrm{H}_{2} \mathrm{O}_{2}$. J. Hazard. Mater. 173, 474-479.

Niu, H., Zhang, D., Zhang, S., Zhang, X., Meng, Z., Cai, Y.Q., 2011. Humic acid coated $\mathrm{Fe}_{3} \mathrm{O}_{4}$ magnetic nanoparticles as highly efficient Fenton-like catalyst for complete mineralization of sulfathiazole. J. Hazard. Mater. 190, 559-565.

Oliveira, L.C.A., Goncalves, M., Guerreiro, M.C., Ramalho, T.C., Fabris, J.D., Pereira, M.C., et al., 2007. A new catalyst material based on niobia/iron oxide composite on the oxidation of organic contaminants in water via heterogeneous Fenton mechanisms. Appl. Catal. A-Gen. 316, 117-124.

Oliveira, L.C.A., Ramalho, T.C., Souza, E.F., Gonçalves, M., Oliveira, D.Q.L., Pereira, M.C., et al., 2008. Catalytic properties of goethite prepared in the presence of $\mathrm{Nb}$ on oxidation reactions in water: computational and experimental studies. Appl. Catal. B-Environ. 83, 169-176.

Ortiz de la Plata, G.B., Alfano, O.M., Cassano, A.E., 2010. Decomposition of 2-chlorophenol employing goethite as Fenton catalyst. I. Proposal of a feasible, combined reaction scheme of heterogeneous and homogeneous reactions. Appl. Catal. BEnviron. 95, 1-13.

Perathoner, S., Centi, G., 2005. Wet hydrogen peroxide catalytic oxidation (WHPCO) of organic waste in agro-food and industrial streams. Top. Catal. 33, 207-224.

Pereira, M.C., Oliveira, L.C.A., Murad, E., 2012. Iron oxide catalysts: Fenton and Fenton-like reactions - a review. Clay Miner. 47, 285-302.

Pestovsky, O., Bakac, A., 2006. Aqueous ferryl(IV) ion: kinetics of oxygen atom transfer to substrates and oxo exchange with solvent water. Inorg. Chem. 45, 814-820.

Pestovsky, O., Bakac, A., 2008. Identification and characterization of aqueous ferryl(IV) ion. In: Sharma, V.K. (Ed.), Ferrates: Synthesis, Properties, and Applications in Water and Wastewater Treatment. American Chemical Society, Washington, DC, pp. 167-176.

Pham, A.L.T., Lee, C., Doyle, F.M., Sedlak, D.L., 2009. A silica-supported iron oxide catalyst capable of activating hydrogen peroxide at neutral pH values. Environ. Sci. Technol. 43, 8930-8935.

Pignatello, J.J., Liu, D., Huston, P., 1999. Evidence for an additional oxidant in the photoassisted Fenton reaction. Environ. Sci. Technol. 33, 1832-1839.

Pignatello, J.J., Oliveros, E., MacKay, A., 2006. Advanced oxidation processes for organic contaminant destruction based on the Fenton reaction and related chemistry. Crit. Rev. Environ. Sci. Technol. 36, 1-84. 
Pinto, I.S.X., Pacheco, P.H.V.V., Coelho, J.V., Lorencon, E., Ardisson, J.D., Fabris, J.D., et al., 2012. Nanostructured delta-FeOOH: an efficient Fenton-like catalyst for the oxidation of organics in water. Appl. Catal. B-Environ. 119, 175-182.

Rahim Pouran, S., Abdul Raman, A.A., Wan Daud, W.M.A., 2014. Review on the application of modified iron oxides as heterogeneous catalysts in Fenton reactions. J. Clean. Prod. 64, 24-35.

Ramirez, J.H., Zea, H.R., Cramer, T., 2014. Degradation of chrysoidin dye by Fenton and photo-Fenton reaction using natural marmatite as catalyst. J. Adv. Oxid. Technol. 17, 389-396.

Ravishankara, A.R., Davis, D.D., 1978. Kinetic rate constants for the reaction of hydroxyl with methanol, ethanol, and tetrahydrofuran at 298 K. J. Phys. Chem. 82, 2852-2853.

Remucal, C.,.K., Sedlak, D.L., 2011. The role of iron coordination in the production of reactive oxidants from ferrous iron oxidation by oxygen and hydrogen peroxide. In: Paul, G.T., Timothy, J.G., Stefan, B.H. (Eds.), Aquatic Redox Chemistry. American Chemical Society, Washington, DC, pp. 177-197.

Seyed Dorraji, M.S., Mirmohseni, A., Carraro, M., Gross, S., Simone, S., Tasselli, F., et al., 2015. Fenton-like catalytic activity of wet-spun chitosan hollow fibers loaded with $\mathrm{Fe}_{3} \mathrm{O}_{4}$ nanoparticles: batch and continuous flow investigations. J. Mol. Catal. A-Chem. 398, 353-357.

Souza, W.F., Guimaraes, I.R., Lima, D.Q., Silva, C.L.T., Oliveira, L.C.A., 2009. Brazilian limonite for the oxidation of quinoline: high activity after a simple magnetic separation. Energy Fuel 23, 4426-4430.

Steiner, M.G., Babbs, C.F., 1990. Quantitation of the hydroxyl radical by reaction with dimethyl-sulfoxide. Arch. Biochem. Biophys. 278, 478-481.

Sun, S.-P., Zeng, X., Li, C., Lemley, A.T., 2014. Enhanced heterogeneous and homogeneous Fenton-like degradation of carbamazepine by nano- $\mathrm{Fe}_{3} \mathrm{O}_{4} / \mathrm{H}_{2} \mathrm{O}_{2}$ with nitrilotriacetic acid. Chem. Eng. J. 244, 44-49.

Tang, W.Z., Chen, R.Z., 1996. Decolorization kinetics and mechanisms of commercial dyes by $\mathrm{H}_{2} \mathrm{O}_{2}$ /iron powder system. Chemosphere 32, 947-958.

Tyre, B.W., Watts, R.J., Miller, G.C., 1991. Treatment of 4 biorefractory contaminants in soils using catalyzed hydrogen-peroxide. J. Environ. Qual. 20, 832-838.

Vanýsek, P., 2011. Electrochemical Series, CRC Handbook of Chemistry and Physics. 92nd ed. CRC Press, Boca Raton, USA.

Wang, H., Huang, Y.M., 2011. Prussian-blue-modified iron oxide magnetic nanoparticles as effective peroxidase-like catalysts to degrade methylene blue with $\mathrm{H}_{2} \mathrm{O}_{2}$. J. Hazard. Mater. 191, 163-169.

Wang, Z., Ma, W., Chen, C., Ji, H., Zhao, J., 2011. Probing paramagnetic species in titania-based heterogeneous photocatalysis by electron spin resonance (ESR) spectroscopy-a mini review. Chem. Eng. J. 170, 353-362.

Wang, J., Liu, C., Tong, L., Li, J., Luo, R., Qi, J., et al., 2015a. Iron-copper bimetallic nanoparticles supported on hollow mesoporous silica spheres: an effective heterogeneous Fenton catalyst for orange II degradation. RSC Adv. 5, 69593-69605.

Wang, Y., Zhao, H., Zhao, G., 2015b. Iron-copper bimetallic nanoparticles embedded within ordered mesoporous carbon as effective and stable heterogeneous Fenton catalyst for the degradation of organic contaminants. Appl. Catal. B-Environ. 164, 396-406.

Xu, L., Wang, J., 2011. A heterogeneous Fenton-like system with nanoparticulate zero-valent iron for removal of 4-chloro-3-methyl phenol. J. Hazard. Mater. 186, 256-264.

$\mathrm{Xu}$, L., Wang, J., 2012a. Fenton-like degradation of 2,4-dichlorophenol using $\mathrm{Fe}_{3} \mathrm{O}_{4}$ magnetic nanoparticles. Appl. Catal. B-Environ. 123, 117-126.

$\mathrm{Xu}$, L., Wang, J., 2012b. Magnetic nanoscaled $\mathrm{Fe}_{3} \mathrm{O}_{4} / \mathrm{CeO}_{2}$ composite as an efficient Fenton-like heterogeneous catalyst for degradation of 4-chlorophenol. Environ. Sci. Technol. 46, 10145-10153.
Xue, X., Hanna, K., Abdelmoula, M., Deng, N., 2009a. Adsorption and oxidation of PCP on the surface of magnetite: kinetic experiments and spectroscopic investigations. Appl. Catal. B-Environ. 89, 432-440.

Xue, X., Hanna, K., Deng, N., 2009b. Fenton-like oxidation of Rhodamine $B$ in the presence of two types of iron (II, III) oxide. J. Hazard. Mater. 166, 407-414.

Xue, X., Hanna, K., Despas, C., Wu, F., Deng, N., 2009c. Effect of chelating agent on the oxidation rate of PCP in the magnetite/ $\mathrm{H}_{2} \mathrm{O}_{2}$ system at neutral pH. J. Mol. Catal. A-Chem. 311, 29-35.

Yan, J., Tang, H., Lin, Z., Anjum, M.N., Zhu, L., 2012. Efficient degradation of organic pollutants with ferrous hydroxide colloids as heterogeneous Fenton-like activator of hydrogen peroxide. Chemosphere 87, 111-117.

Yang, S., He, H., Wu, D., Chen, D., Liang, X., Qin, Z., et al., 2009. Decolorization of methylene blue by heterogeneous Fenton reaction using $\mathrm{Fe}_{3-\mathrm{x}} \mathrm{Ti}_{\mathrm{x}} \mathrm{O}_{4}(0 \leq \mathrm{x} \leq 0.78)$ at neutral $\mathrm{pH}$ values. Appl. Catal. B-Environ. 89, 527-535.

Yurii, D.P., Virender, K.S., 2008. Higher oxidation states of iron in solid state: synthesis and their Mössbauer characterization. In: Virender, K.S. (Ed.), Ferrates. American Chemical Society, Washington, DC, pp. 112-123.

Zelmanov, G., Semiat, R., 2008. Phenol oxidation kinetics in water solution using iron(3)-oxide-based nano-catalysts. Water Res. 42, 3848-3856.

Zeng, X., Lemley, A.T., 2009. Fenton degradation of 4,6-dinitro-ocresol with $\mathrm{Fe}^{2+}$-substituted ion-exchange resin. J. Agric. Food Chem. 57, 3689-3694.

Zhang, S., Zhao, X., Niu, H., Shi, Y., Cai, Y., Jiang, G., 2009. Superparamagnetic $\mathrm{Fe}_{3} \mathrm{O}_{4}$ nanoparticles as catalysts for the catalytic oxidation of phenolic and aniline compounds. J. Hazard. Mater. 167, 560-566.

Zhang, X.Q., Gong, S.W., Zhang, Y., Yang, T., Wang, C.Y., Gu, N., 2010. Prussian blue modified iron oxide magnetic nanoparticles and their high peroxidase-like activity. J. Mater. Chem. 20, 5110-5116.

Zhang, Y., He, C., Sharma, V.K., Li, X.Z., Tian, S., Xiong, Y., 2011. A coupling process of membrane separation and heterogeneous Fenton-like catalytic oxidation for treatment of acid orange II-containing wastewater. Sep. Purif. Technol. 80, 45-51.

Zhang, L., Nie, Y., Hu, C., Qu, J., 2012. Enhanced Fenton degradation of Rhodamine B over nanoscaled Cu-doped $\mathrm{LaTiO}_{3}$ perovskite. Appl. Catal. B-Environ. 125, 418-424.

Zhang, Y., Zhang, K., Dai, C., Zhou, X., Si, H., 2014. An enhanced Fenton reaction catalyzed by natural heterogeneous pyrite for nitrobenzene degradation in an aqueous solution. Chem. Eng. J. $244,438-445$

Zhao, J.C., Wu, T.X., Wu, K.Q., Oikawa, K., Hidaka, H., Serpone, N., 1998. Photoassisted degradation of dye pollutants. 3 . Degradation of the cationic dye Rhodamine B in aqueous anionic surfactant/TiO 2 dispersions under visible light irradiation: evidence for the need of substrate adsorption on $\mathrm{TiO}_{2}$ particles. Environ. Sci. Technol. 32, 2394-2400.

Zheng, C., Cheng, X., Chen, P., Yang, C., Bao, S., Xia, J., et al., 2015. Highly porous $\mathrm{Fe}_{2} \mathrm{O}_{3} / \mathrm{KIT}-6$ with Mg substitution for heterogeneous Fenton oxidation of imidacloprid with enhanced catalytic activity. Chem. Lett. 44, 601-603.

Zhou, T., Li, Y., Ji, J., Wong, F.S., Lu, X., 2008. Oxidation of 4-chlorophenol in a heterogeneous zero valent iron $/ \mathrm{H}_{2} \mathrm{O}_{2}$ Fenton-like system: kinetic, pathway and effect factors. Sep. Purif. Technol. 62, 551-558.

Zubir, N.A., Zhang, X., Yacou, C., da Costa, J.C.D., 2014. Fenton-like degradation of acid orange 7 using graphene oxide-iron oxide nanocomposite. Sci. Adv. Mater. 6, 1382-1388.

Zubir, N.A., Yacou, C., Motuzas, J., Zhang, X., Zhao, X.S., Diniz da Costa, J.C., 2015. The sacrificial role of graphene oxide in stabilising a Fenton-like catalyst $\mathrm{GO}-\mathrm{Fe}_{3} \mathrm{O}_{4}$. Chem. Commun. 51, 9291-9293. 